\title{
Production of fiberboards from rice straw thermo-mechanical extrudates by thermopressing: influence of fiber morphology, water and lignin content
}

Dyna Thenga,c, Gerard Arbat ${ }^{\mathrm{b}}$, Marc Delgado-Aguilar ${ }^{\mathrm{a}}$, Bunthan Ngo $^{\mathrm{c}}$, Laurent Labonne ${ }^{\mathrm{d}}$, Pere Mutjéa Philippe Evon $^{\mathrm{d} *}$

${ }^{\text {a }}$ LEPAMAP research group, University of Girona, C/ Maria Aurèlia Capmany, 61, 17003 Girona, Spain

${ }^{\mathrm{b}}$ Department of Chemical and Agricultural Engineering and Food Technology, University of Girona, C/ Maria Aurèlia Capmany, 61, 17003 Girona, Spain

${ }^{\mathrm{c}}$ Royal University of Agriculture, 2696, Phnom Penh, Cambodia

${ }^{\mathrm{d}}$ Laboratoire de Chimie Agro-industrielle (LCA), Université de Toulouse, ENSIACET, INRA, INPT, Toulouse Cedex 4, France

$$
\text { *Corresponding author: Philippe.Evon@ensiacet.fr (Ph. Evon) }
$$

\section{Abstract}

The objective of this study was to investigate the influence of fiber morphology and molding parameters on mechanical and physical properties of fiberboards made from rice straw. The rice straw was thermo-mechanically treated using a twin-screw extruder. Water added at molding (0-20\%), lignin content (0-25\%), and liquid/solid ratio used for extrudate production (0.33-1.07) were the three parameters investigated. A Doehlert's experimental design was used to evaluate their influence on boards' properties. The results revealed that 0.4 liquid/solid ratio at extrudate production, $5 \%$ water added at molding, and 8.9\% lignin content were the best tested conditions for bending properties. Density of fiberboard produced from these conditions was $1414 \mathrm{~kg} / \mathrm{m}^{3}$ (i.e. the densest board). Maximum flexural strength and elastic modulus were 50.3 MPa and 8.6 GPa, respectively. Thickness swelling and water absorption were 23.6\% and 17.6\%, respectively. Using the statistical analysis of the experimental design, a good compromise between density and flexural properties should be obtained from $0 \%$ water added, $25 \%$ lignin content, and 0.33 liquid/solid ratio at extrudate production. From the polynomial models, the corresponding boards' properties should be approximately 50 MPa maximum flexural strength, $6.0 \mathrm{GPa}$ elastic modulus, $1102 \mathrm{~kg} / \mathrm{m}^{3}$ density, and $24 \%$ thickness swelling.

Keywords: Twin-screw extruder, thermo-mechanical treatment, fiberboard. 


\section{Introduction}

Lignocellulosic biomass has been acknowledged for potential use in natural composites production. Such application of the biomass usually requires a pretreatment, e.g. mechanical, thermal or chemical pretreatment or their combinations (Zhang et al. 2015). As for all lignocellulosic materials, the two main components inside rice straw are cellulose and then hemicelluloses. These two carbohydrate polymers have the form of a heterogeneous complex. The latter is impregnated with layers of lignin which has the form of a three-dimensional hydrophobic network around cellulose and hemicelluloses. The main purposes of lignin inside plants are to provide rigidity, impermeability to water and a high resistance to decomposition. Thus, in order to release cellulose and hemicelluloses, a pretreatment step is necessary to break lignin seal. As an example, the defibration of different lignocellulosic biomass sources was recently conducted through twin-screw extrusion using thermo-mechanical and thermo-mechano-chemical pretreatments. The wall polymers were thus destructured. And, once released, cellulose was in that specific case subsequently transformed into glucose through enzymatic hydrolysis (i.e. saccharification) and then into second-generation bioethanol (Vandenbossche et al. 2016).

Extrusion is a promising thermo-mechanical pretreatment method for biomass conversion because of its low cost, good monitoring of temperature and screw speed, high shear, and excellent processing ability. Single-screw and twin-screw extruders are widely used in the snack food, feed, plastic, and composites industries. Although both types of extruders are used in extrusion processes, twin-screw extruders are preferable than single-screw ones, due to the greater control of residence time distribution and mixing, and also higher capacity of heat and mass transfer (Lin et al. 2012).

As an example, the twin-screw extrusion technology appears as an original and powerful solution for the biorefinery of sunflower whole plant (Evon et al. 2010). The twin-screw extruder leads to a highly effective, mechanical cell lysis in a single step following a continuous process (Evon et al. 2015). Recently, Vandenbossche et al. (2015) also used the twin-screw extrusion technology for conducting the thermo-mechanical and thermo-mechano-chemical pretreatment of different lignocellulosic biomass sources, not for the subsequent manufacture of composite materials but for the production of second-generation bioethanol using a biocatalytic action. The use of a twin-screw extruder to pretreat fibers from agricultural wastes for composites (e.g. fiberboard manufacturing) was cheaper than other defibring technologies, e.g. about nine times less expensive compared to a digestion plus defibration process using a rotary digester and then a Sprout-Waldron defibrator (Theng et al. 2017a). Moreover, because no compound has been removed from the solid material during the thermo-mechanical treatment in the twin-screw extruder, there was no change on both chemical and thermal properties between the raw biomass (i.e. rice straw) and the extrudates obtained. 
As these extrudates are mixtures of lignocellulosic fibers, they could be potentially processed by thermo-pressing into cohesive fiberboards. In recent works, Evon et al. $(2014,2015)$ produced self-bonded fiberboards from a cake generated during the biorefinery of sunflower whole plant in a Clextral (France) BC 45 twin-screw extruder, using a heated hydraulic press. Additionally, it was the cake’s proteins that acted as a natural binder inside boards, thus ensuring their mechanical cohesion.

For rice straw extrudates, the board's cohesion could be obtained through lignin addition. Indeed, lignin is the most important chemical for self-bonding and for water resistance of fiber-based molded objects without binder agents (Mason 1928). The lignin was melt and created a welding effect during the molding operation. According to Van Dam et al. (2004), steam explosion lignin and organosolv lignin are very reactive and can be used as a bonding agent for particleboards. They could replace up to $50 \%$ of synthetic binders (i.e. phenolic based resins), although their effective use for such application remains uncertain on an industrial scale (Gosselink et al. 2011). In particular, Kraft and organosolv lignin were recently used with success at a laboratory scale for producing fiberboards from rice straw thermos-mechanical pulp (Theng 2017) and raw shives (Evon et al. 2018), the by-product of the continuous fiber mechanical extraction from oleaginous flax straw (Evon et al. 2017). Indeed, when adding 13\% of Kraft lignin to the rice straw thermos-mechanical pulp the flexural strength increased from 40.4 to $53.5 \mathrm{MPa}$ and adding $25 \%$ organosolv lignin (wt\% relative to the raw shives), an important increase in the maximum flexural strength was evidenced (from 2.1 to $8.0 \mathrm{MPa}$ ), illustrating the role of this additional lignin as a natural binder inside the fibrous material. Nevertheless, despite this lignin addition, it appeared that these flexural properties still remained limited for subsequent uses.

Previous studies using thermogravimetric and especially differential scanning calorimetry methods revealed that a first endothermic event took place at around $150{ }^{\circ} \mathrm{C}$ for lignin, the latter being attributed to the fusion of lignin (Kim and Dale 2004, Murugan et al. 2008). Some other endothermic peaks above $180{ }^{\circ} \mathrm{C}$ were also observed, and they were associated with physical and/or chemical changes of lignin. However, they were difficult to fully explain, due to the complex structure of lignin. This irreversible change in lignin after being heated over $180{ }^{\circ} \mathrm{C}$ would possibly be related to the "lignin activation” phenomenon, i.e. the partial depolymerization to obtain new linkage capability (Mobarak et al. 1982). The activated lignin would have reduced melting point, and capacity to polycondensate.

This study aimed to assess the feasibility of producing novel biodegradable fiberboards by thermo-pressing from rice straw extrudates prepared using a Clextral Evolum HT 53 pilot-scale twin-screw extruder, and to study the influence of the molding parameters (i.e. water added at molding, lignin content, and liquid/solid ratio used for the extrudate production) on the mechanical and physical properties of the resulting fiberboards. 


\section{Materials and methods}

2.1 Material

The starting material was a single batch of rice straw (Oriza Sativa L.), i.e. the whole plant except the panicle and the grain. The rice straw was of French origin and it was purchased from the JCL AGRI company (Bouge-Chambalud, France). The rice was harvested in October at plant maturity. The moisture content of rice straw was $7.4 \pm 0.2 \%$ (French standard NF V 03-903). Its chemical composition, expressed in \% of dry matter, was as follows: $14.7 \pm 0.1 \%$ minerals (French standard NF V 03-322), $37.7 \pm 0.3 \%$ cellulose (ADF-NDF method), $27.9 \pm 0.4 \%$ hemicelluloses (ADF-NDF method), $7.2 \pm 0.1 \%$ lignin (ADF-NDF method), and $16.0 \pm 0.1 \%$ water-soluble components (mass loss after $1 \mathrm{~h}$ in boiling water). Before to produce the extrudate the straw was crushed using a hammer mill (Elecra BC P, France) fitted with a 6 mm screen.

The lignin powder used in this study was supplied by CIMV (Compagnie Industrielle de la Matière Végétale, Labège, France). Called Biolignin ${ }^{\mathrm{TM}}$, this product was presented as a brown color powder obtained from wheat straw (CIMV 2014). The main characteristics of Biolignin ${ }^{\mathrm{TM}}$ are presented in Table 1.

Thermo-mechanical fractionation of rice straw was then conducted using a pilot-scale Clextral (France) Evolum HT 53 co-penetrating and co-rotating twin-screw extruder to produce the materials (i.e. the extrudates) used for the fiberboard manufacturing. The extrudates were obtained using three different liquid/solid (L/S) ratios at extrusion, i.e. 1.0, 0.7 and 0.4 , respectively. The details for the extrudate preparation (including the extrusion process, the sampling procedure, and the description of the equipment used for defibring) are described in the supplementary material 1. Before molding, the extrudates were previously crushed using a hammer mill (Electra VS 1, France) fitted with a 15 mm screen to minimize the risk of defects like aggregation, degassing, and blisters inside the fiberboards at thermo-pressing. The moisture content of the extrudates was about 7\% (French standard NF V 03-903). The dry weight of extrudate used for each molding experiment was $100 \mathrm{~g}$ (i.e. $444 \mathrm{mg} / \mathrm{cm}^{2}$ ).

\subsection{Fiber matrix preparation before molding}

Biolignin $^{\mathrm{TM}}$ at a certain proportion (Table 2) and $500 \mathrm{~mL}$ distilled water were mixed with the $100 \mathrm{~g}$ dry weight of extruded fibers. Here, more water than the required moisture content values (i.e. $0-20 \%$ ) at molding was added to guarantee an efficient mixing between lignin powder and extruded fibers. The mixture was then stirred manually in a plastic container for a good mix, and then it was air-dried overnight at room temperature on a nylon cloth, subsequently. The prepared material was dried in a ventilated oven at $80^{\circ} \mathrm{C}$ in the morning of the next day until the desired moisture 
content for molding. Depending on the thermo-pressing conditions used, the latter corresponded to water added at molding varying from 0.0 to $20.0 \%$ (Table 2 ).

2.3 Thermo-pressing

The molding was performed by thermo-pressing inside an aluminum mold. A 400 ton capacity Pinette Emidecau Industries (France) heated hydraulic press was used to produce $3 \mathrm{~mm} \times 150 \mathrm{~mm} \times 150 \mathrm{~mm}$ fiberboards. Fourteen fiberboards were manufactured using different molding parameters according to a Doehlert's experimental design with three variables, i.e. water added at molding (from 0 to $20 \%$ in weight, in proportion to the dry weight of extruded fibers), lignin content (from 0 to $25 \%$ in weight, in proportion to the dry weight of extruded fibers) and liquid/solid ratio used for the extrudate production (from 0.33 to 1.07 ) (Table 2).

Looking at the minimum values for both water added at molding and lignin content, they were chosen equal to $0 \%$ in order to simulate the direct hot pressing of rice straw extrudates, that is to say without adding neither water at molding nor the ligneous binder. In parallel, maximum values (20\% and 25\%, respectively) were chosen in the same order of magnitude as for a previous study from Theng et al. (2017b) using a corn stalk thermo-mechanical pulp as raw material and kraft lignin as green adhesive. For the L/S ratio at extrusion, minimum and maximum values originated from a previous work of Theng et al. (2017a) using rice straw as starting material: with less than $0.33 \mathrm{~L} / \mathrm{S}$ ratio, the fiber length would have been greatly reduced during the twin-screw defibration treatment, simultaneously with an important increase in the total production cost, whereas the use of L/S ratios more than 1.07 would have resulted in the filling of the twinscrew machine with water going back to the feeding module, thus preventing the proper introduction of rice straw.

The Doehlert's experimental design used in this study is presented in Table 2. In particular, Table 2 mentions the three coding values $\left(\mathrm{X}_{\mathrm{i}}\right.$, i varying from 1 to 3 ) tested for the manufacture of each of the fourteen fiberboards, and related to the three molding parameters studied: water added at molding, lignin content and L/S ratio during extrusion, respectively. In an experimental point of view, the real molding parameters used for producing boards number 1 to 14 were calculated from these coding values, each coding value possibly varying from -1.0 (associated with the minimum value of the corresponding molding parameter) to 1.0 (associated with the maximum value of the corresponding molding parameter). These molding parameters are also all appearing in Table 2.

The other molding conditions (i.e. applied pressure, mold temperature and molding time) were fixed as a nonvariable parameter with two cycles of pressing as follows:

1. Hot pressing at 22.3 MPa (pressure expressed as the force per unit of molded fiberboard surface) and $200{ }^{\circ} \mathrm{C}$ during $5 \mathrm{~min}$. After, the pressure was decreased at a $0.2 \mathrm{MPa} / \mathrm{s}$ speed to $1.0 \mathrm{MPa}$ with a constant temperature. Then, the 
temperature was reduced to $60^{\circ} \mathrm{C}$ while maintaining a 1.0 MPa applied pressure. Finally, the mold was opened using an automatic control means. Taking into account the cooling step, the overall duration of this first cycle was about 30 min. Each panel was then cooled at room temperature during $2 \mathrm{~h}$ and half, and no significant change in its moisture content was observed during this cooling step.

2. After cooling the fiberboard at room temperature, it was hot pressed again at $11.2 \mathrm{MPa}$ and $200{ }^{\circ} \mathrm{C}$ during 1 min. The end of this cycle was conducted using the same procedure as for the first one, i.e. by decreasing the pressure firstly to $1.0 \mathrm{MPa}$, and then reduce the temperature to $60{ }^{\circ} \mathrm{C}$ before the mold was automatically opened. Taking into account the cooling step, the overall duration of this second cycle was about $20 \mathrm{~min}$.

The $200{ }^{\circ} \mathrm{C}$ molding temperature, which is higher than the lignin glass transition temperature, was selected to reach a rubbery state for Biolignin ${ }^{\mathrm{TM}}$ during molding. Such temperature led to the best bending properties according to Mancera et al. (2012). In parallel, looking at the TGA results for Biolignin ${ }^{\mathrm{TM}}$ and rice straw thermo-mechanical extrudates (Theng et al. 2017a), the molding temperature was under the beginning of thermal degradation of organic compounds inside both binder and lignocellulosic fibers of extrudates. Applied pressure and molding duration were chosen for a target fiberboard's thickness of 3 mm, according to parameters already used in previous studies (Anglès et al. 2001, Mancera et al. 2012, Theng et al. 2017b).

Statistical analysis of the results from the Doehlert’s experimental design was conducted using the NEMRODW ${ }^{\circledR}$ software (NEMRODW 2015), which was also used to plot the isoresponse curves.

The best-fit second-order response (Y) obtained to describe each of the fiberboard characteristics (i.e. flexural properties, Charpy impact strength, Shore $D$ surface hardness, thickness swelling, water absorption, and color) was given by the following formula:

$\mathrm{Y}=\mathrm{a}_{0}+\left(\mathrm{a}_{1} \times \mathrm{X}_{1}\right)+\left(\mathrm{a}_{2} \times \mathrm{X}_{2}\right)+\left(\mathrm{a}_{3} \times \mathrm{X}_{3}\right)+\left(\mathrm{a}_{11} \times \mathrm{X}_{1} \times \mathrm{X}_{1}\right)+\left(\mathrm{a}_{22} \times \mathrm{X}_{2} \times \mathrm{X}_{2}\right)+\left(\mathrm{a}_{33} \times \mathrm{X}_{3} \times \mathrm{X}_{3}\right)+\left(\mathrm{a}_{12} \times \mathrm{X}_{1}\right.$ $\left.\times \mathrm{X}_{2}\right)+\left(\mathrm{a}_{13} \times \mathrm{X}_{1} \times \mathrm{X}_{3}\right)+\left(\mathrm{a}_{23} \times \mathrm{X}_{2} \times \mathrm{X}_{3}\right)$

Where: $\mathrm{X}_{1}, \mathrm{X}_{2}$, and $\mathrm{X}_{3}$ are the coding values of the experimental design, each varying from -1.0 to 1.0 , and relative to the three molding parameters tested (water added at molding, lignin content, and L/S ratio used for the extrudate production, respectively), and $a_{i}$ (i varying from 0 to 3 ), and $a_{i j}$ ( $i$ and $j$ varying from 1 to 3 , and $i \leq j$ ) the coefficients of the polynomial model.

For each fiberboard characteristic, the significance of the coefficients of its best-fit second-order response was estimated thanks to the comparison of their absolute values with the associated standard deviations. The $a_{i}$ and $a_{i j}$ 
coefficients were considered as significant when their absolute values were higher than the standard deviations. On the contrary, they were considered as non-significant when the standard deviations were higher.

Three fiberboards were produced for each tested molding condition in order to have replicability. Immediately after molding, these were conditioned in a climatic chamber $\left(60 \% \mathrm{RH}, 25^{\circ} \mathrm{C}\right)$ for four weeks. A first fiberboard was used to assess thickness, apparent density, and mechanical properties for bending. After conditioning, four 30 mm wide test specimens were cut, measured their thickness at three points and their length at two points, using a $0.01 \mathrm{~mm}$ resolution electronic digital sliding caliper. Thickness, length and weight were recorded to calculate the specimen volume and density. The thickness $(t)$ and apparent density $(d)$ of fiberboard were the mean values of measurements made on the four test specimens. A second fiberboard was used for measuring: Shore $D$ surface hardness and Charpy impact strength. The third fiberboard was used for thickness swelling and water absorption.

\subsection{Mechanical properties of bending}

Measurement of the flexural properties of the test specimens according to French standard NF EN 310 was undertaken using an Instron 33R4204 (USA) universal testing machine fitted with a $500 \mathrm{~N}$ load cell, and the three points bending technique. Test specimens were $150 \mathrm{~mm}$ long and $30 \mathrm{~mm}$ wide, and their thickness was measured thanks to the use of an electronic digital sliding caliper having a $0.01 \mathrm{~mm}$ resolution. Test speed was $2 \mathrm{~mm} / \mathrm{min}$ with a grip separation of $100 \mathrm{~mm}$. Load was applied equidistant from the two supports, and the loading direction was perpendicular to the upper face of the test specimen. Properties covered breaking load $(F)$, maximum flexural strength $\left(\sigma_{\mathrm{f}}\right)$, and elastic modulus $\left(E_{\mathrm{f}}\right)$. All determinations were carried out four times, i.e. from each of the four test specimens cut in each fiberboard.

\subsection{Charpy impact strength}

The impact strength of unnotched test specimens according to French standard NF EN ISO 179 was assessed with a Test-well Wolpert 0-40 daN cm (France) Charpy machine, and this also covered absorbed energy $(W)$, and impact resilience $(K)$. Eight test specimens of $60 \mathrm{~mm}$ long and $10 \mathrm{~mm}$ wide were cut. To calculate their section, thickness was measured at three points with a $0.01 \mathrm{~mm}$ resolution electronic digital sliding caliper, and the mean value of thickness recorded. Impact strength measurements were made at $23^{\circ} \mathrm{C}$ using the three points bending technique, with a $25 \mathrm{~mm}$ grip separation. Load was applied equidistant from the two supports, and the loading direction was perpendicular to the test specimen. All determinations were carried out eight times, i.e. from each of the eight test specimens cut in each fiberboard. 
Shore $D$ surface hardness of the fiberboards was assessed using a Bareiss (Germany) durometer according to French standard NF EN ISO 868. The indentation direction was perpendicular to the upper face of the fiberboard. All determinations were carried out 48 times for each fiberboard (24 times for each board side).

\subsection{Color measurement}

Color of the fiberboard specimens was measured using a Konica Minota CR-410 (Japan) spectrophotometer. The color measurements were made using the CIE $\mathrm{L}^{*} \mathrm{a} * \mathrm{~b} *$ referential, which is widely employed for non-luminous objects. The illuminant was D65, and the observer angle was $2^{\circ}$. In the $\mathrm{L}^{*} \mathrm{a}^{*} \mathrm{~b}^{*}$ color space, $\mathrm{L}^{*}$ is the lightness and it varies from 0 (black) to 100 (white), and $a^{*}$ and $b^{*}$ are the chromaticity coordinates: $+a^{*}$ is the red direction, - $\mathrm{a}^{*}$ is the green direction, $+\mathrm{b}^{*}$ is the yellow direction, and $-\mathrm{b}^{*}$ is the blue direction. The center is achromatic (Konica Minolta Sensing 2007). All determinations were carried out 48 times on each fiberboard specimen, i.e. 24 times for each board side.

The measured $\mathrm{L}^{*}$ color values were used to estimate the darkening of the fiberboard compared to the color of the starting material, i.e. rice straw. In addition, the color difference $\left(\Delta \mathrm{E}^{*}\right)$ between the rice straw and each fiberboard was calculated using the following formula:

$$
\Delta \mathrm{E}^{*}=\sqrt{(\Delta L *)^{2}+(\Delta a *)^{2}+(\Delta b *)^{2}}
$$

\subsection{Thickness swelling and water absorption}

Four $50 \mathrm{~mm} \times 50 \mathrm{~mm}$ samples were used to determine thickness swelling (TS) and water absorption (WA) of the fiberboards. To evaluate these, they were submerged in distilled water at $25^{\circ} \mathrm{C}$ for $24 \mathrm{~h}$. TS was calculated following French standard NF EN 317, and thickness of each sample was measured at four points midway along each side, $10 \mathrm{~mm}$ from the edge before and after soaking in distilled water. Each sample was also weighed to an accuracy of $0.01 \mathrm{~g}$ to estimate WA values, where

$$
\mathrm{WA}=\left(\mathrm{m}_{2}-\mathrm{m}_{1}\right) / \mathrm{m}_{1} \times 100
$$

and $m_{1}$ and $m_{2}$ are the weights of the sample before and after immersion.

2.9 Analytical methods

Before each analysis, the materials (i.e. rice straw and extrudates) were milled using a Foss (Denmark) Cyclotec 1093 cutting mill fitted with a $1 \mathrm{~mm}$ screen. The moisture contents were determined according to the French standard NF V 03-903. The mineral contents were determined according to the French standard NF V 03-322. An estimation of the 
three parietal constituents (cellulose, hemicelluloses, and lignins) was made using the ADF-NDF method of Van Soest and Wine $(1967,1968)$. An assessment of the water-soluble components was made by measuring the mass loss of the test sample after $1 \mathrm{~h}$ in boiling water. All analyses were carried out in duplicate.

\subsection{Thermogravimetric analysis measurement}

Thermogravimetric analysis (TGA) of Biolignin ${ }^{\mathrm{TM}}$ was carried out using a Shimadzu TGA-50 (Japan) analyzer. Dynamic analysis was conducted under air atmosphere at a heating rate of $5^{\circ} \mathrm{C} / \mathrm{min}$, from 25 to $800{ }^{\circ} \mathrm{C}$. The mass of the test sample was around $8 \mathrm{mg}$. The weight of sample was measured as a function of temperature. These data were later used to plot the percentage of undegraded sample (1 - D) (\%) as a function of temperature, where

$$
\mathrm{D}=\left(\mathrm{W}_{0}-\mathrm{W}\right) / \mathrm{W}_{0}
$$

and $W_{0}$ and $W$ are the weights at the starting point and during scanning (mg). Measurements were carried out in duplicate.

\subsection{Morphological analysis of fibers inside extrudates}

The morphological analysis of extrudates was carried out using a MorFi Compact analyzer (TechPap, France) equipped with a CCD video camera. About 30,000 fibers were analyzed by the MorFi v9.2 software. Among other parameters, this software was able to calculate mean fiber length, mean diameter and fines percentage (fibers shorter than $76 \mu \mathrm{m})$. All characterizations were performed in duplicate.

In the procedure of the fibers preparation, $2.5 \mathrm{~g}$ of dried mass extrudate was taken to dilute in $1000 \mathrm{ml}$ and stirred by a mechanical stirrer to breakdown the aggregate. Then, $100 \mathrm{ml}$ of the mixture was poured into another beaker and filled up using distilled water for $1000 \mathrm{ml}$ (1:10 dilution). Making the same way for 4 beakers to represent of four replications for each sample analysis.

\subsection{Apparent and tapped densities}

Tapped density was measured using a Granuloshop Densitap ETD-20 (France) volumenometer fitted with a 250 $\mathrm{mL}$ graduated cylinder. Before compaction, apparent density was also measured. All measurements were conducted in duplicate.

\subsection{Statistical analysis}

For both chemical composition and fiber morphology of the extrudates, all determinations were conducted in duplicate. Data were expressed as means \pm standard deviations. The means were compared following one-way analysis of variance (ANOVA) using the software PAWS Statistics 18 data analysis. The comparison between the different 
individual means was performed using Duncan’s multiple range test at a 5\% probability level. Thus, in the two related tables, means in the same column and with the same superscript letter were not significantly different at $\mathrm{P}<0.05$.

\section{Results and Discussion}

3.1 Physico-chemical characterization of the extrudates

Table 3 shows the chemical composition of rice straw before and after twin-screw extrusion. The thermomechanical treatment applied in the twin-screw extruder did not affect noticeably the composition, whether the L/S ratio was high (1.0, i.e. $E_{1}$ extrudate) or low (0.4, i.e. $E_{3}$ extrudate). Indeed, the four chemical compositions were quite comparable with contents in cellulose, hemicelluloses, lignins, and water-soluble components ranging from 34 to $38 \%$, from 28 to 33\%, from 6 to 7\%, and from 16 to 17\%, respectively. The thermal gravimetric analysis of the extrudates was also conducted (see supplementary material 2). And, as for chemical composition, TGA results were equivalent for both rice straw and extrudates, meaning that the thermo-mechanical treatment applied to the rice straw did not increase its thermal stability.

Table 4 shows the main morphological characteristics of fibers in the extrudates $\left(E_{1}\right.$ to $\left.E_{3}\right)$, produced using different operating conditions, before and after crushing in the hammer mill fitted with a $15 \mathrm{~mm}$ screen. Such characteristics were determined using a MorFi Compact analyzer, and they include length, diameter, and aspect ratio (defined as the ratio of the length to the diameter) of fibers, and fine content in the extrudates. From the mean length $\left(L_{W}\right)$ and diameter $(D)$ of the extruded fibers, the corresponding $L_{W} / D$ aspect ratios were in the 20.9-22.6 range before crushing. The decrease in the aspect ratio observed as the L/S ratio used for the extrudate production decreased from 1.0 to 0.4 resulted mainly in the decrease of the mean length of fibers from 571 to $494 \mu \mathrm{m}$ (i.e. -14\%) (Table 4). This illustrated that higher mechanical shear and higher self-heating of the material produced by the reversed screws caused low L/S ratios in the twin-screw extruder due to a more intensive fiber cutting. It can be seen clearly according to the statistical analysis of data that the morphological properties of fibers in extrudates $\mathrm{E}_{1}$ and $\mathrm{E}_{2}$ (i.e. 1.0 and $0.7 \mathrm{~L} / \mathrm{S}$ ratios, respectively) were not significantly different. On the contrary, fibers inside extrudate $\mathrm{E}_{3}$ (i.e. $0.4 \mathrm{~L} / \mathrm{S}$ ratio) were actually significantly shorter.

Table 4 also shows the morphological properties of extrudates after passing through the hammer mill fitted with a $15 \mathrm{~mm}$ screen. Depending on the L/S ratio used for the extrudate production, the mean length and the mean aspect ratio of fibers were in the 346-270 $\mu \mathrm{m}$ and 15.0-11.3 ranges, respectively. The reduction of the mean length indicates that hammer mill did not only break the fiber aggregates, but it also contributed in cutting the fibers. The aspect ratio was 
approximately 50\% reduced compared with fibers inside the extrudates before crushing. After the crushing step, the shortest fibers and the lowest aspect ratio were obtained with the lowest value of L/S ratio used for the extrudate production (i.e. 0.4). Then, mean length and mean aspect ratio of fibers of the three extrudates was significantly different.

Usually, longer fibers provide better strength properties in composite materials. However, Shen (1986) claimed that a smaller size of fibers inside composite products made from sugar (used here as a bonding agent) and different lignocellulosic materials (e.g. sugarcane bagasse, and stalks of sorghum, corn, sunflower, flax) could also have a positive effect for molding as it increases the specific surface area and facilitates the accessibility to inner cell wall components, thus contributing to the increase in the mechanical properties of boards. Even if the crushing step was primarily conducted to break the fiber aggregates, thus facilitating the subsequent mixture between the extrudate, lignin and water, it also contributed to a shortening of the fibers (Table 4) and this is reasonable to assume that such cutting will thus possibly contribute to improve bending properties of the boards.

The morphological fibers distribution in the extrudates (Table 4) revealed also the presence of small particles (fibers shorter than $76 \mu \mathrm{m}$ ). This population contained not only the smallest fibers but also spherical particles, i.e. fines, originating from the thermo-mechanical breakdown process of rice straw plus the crushing extra step, corresponding to 63.8\% and 86.6\% maximal values before and after crushing, respectively. Lastly, apparent and tapped densities of the extrudates were quite low, with maximal values before crushing of $162 \mathrm{~kg} / \mathrm{m}^{3}$ and $216 \mathrm{~kg} / \mathrm{m}^{3}$, respectively, and maximal values after crushing of $104 \mathrm{~kg} / \mathrm{m}^{3}$ and $145 \mathrm{~kg} / \mathrm{m}^{3}$, respectively (Fig. 1).

3.2 Thermal stability of Biolignin ${ }^{T M}$

From the experimental design, lignin powder was added to the rice straw extrudates with a content varying from 0 to 25\%, comparable to values used in previous studies (Anglès et al. 2001, Mancera et al. 2012, Theng et al. 2017b). According to Mason (1928) and Back (1987), lignin, based on its polyphenolic structure, is the most important chemical for self-bonding (i.e. intra-fiber bonding) and for water resistance of fiber-based molded objects free of synthetic resin. During thermal pressing at molding, the matrix components, including lignin, flow out the cell walls to fill the gaps between the fiber particles (Takahashi et al. 2010). The presence of water facilitates the separation of the cell wall components during flow testing at high pressure (Yamashita et al. 2009), due to a lower softening point of lignin (plasticization) and to a better heat transfer (Xu et al. 2006). Throughout hot pressing, thermal degradation has been reported following the increasing of temperature (Okuda et al. 2006). The thermogravimetric analysis of lignin powder used in this study was thus conducted, and the TGA degradation curve is shown in Fig. 2. A first mass loss was observed at $100{ }^{\circ} \mathrm{C}$, corresponding to the water evaporation. Its moisture content was about $4 \%$ (Table 1 ), and the mass loss observed in the corresponding TGA curve was associated approximately with the same mass loss percentage. Then, the 
thermal degradation of organic compounds took place in two successive stages (between 150 and $325^{\circ} \mathrm{C}$, and between 350 and $450{ }^{\circ} \mathrm{C}$, respectively), leading to a mass loss of approximately $40 \%$ and $55 \%$, respectively, of the test sample dry mass. As regards the second TGA degradation phenomenon observed at high temperature (i.e. $350-450{ }^{\circ} \mathrm{C}$ ) which also corresponds to the main one, it could correspond essentially to the degradation of lignin. However, because the TGA analysis was conducted under air atmosphere, part of this second thermal degradation stage could also correspond to the oxidation of primary degradation products originating from the previous degradation phenomenon (Uitterhaegen et al. 2016), which in the case of Biolignin ${ }^{\mathrm{TM}}$ resulted from the degradation of the protein and hemicellulose fractions. At the end of TGA measurement, the undegraded sample accounted for less than $2 \%$ of the test sample mass, corresponding to the minerals contained in the lignin powder (Table 1). In conclusion, taking into account the fact that the molding temperature was $200{ }^{\circ} \mathrm{C}$ and because the lignin thermal degradation occurred from $350{ }^{\circ} \mathrm{C}$, it is reasonable to assume that the ligneous binder did not degrade thermally during molding.

3.3 Mechanical and physical properties of fiberboards

From the experimental design, fiberboards produced were all cohesive, including those for which the amount of lignin added was minimal (i.e. only $1.7 \%$ content). Their densities were in the $1239-1414 \mathrm{~kg} / \mathrm{m}^{3}$ range (Table 5), thus making these renewable materials considered as hardboards. The density of the equilibrated fiberboards was not influenced significantly by all the molding parameters tested. This was illustrated by the very low value for the $\mathrm{a}_{3}$ coefficient of the associated polynomial model (i.e. 4.5), compared with the $\mathrm{a}_{1}$ and $\mathrm{a}_{2}$ ones (i.e. -23.9 and -41.5 , respectively) (Table 7). In addition, because $\mathrm{a}_{1}$ and $\mathrm{a}_{2}$ coefficients were negative, this revealed that more water added at molding and/or especially a higher amount of lignin will contribute to a lowering of the density of fiberboard. On the contrary, although it is non-significant, the $\mathrm{a}_{3}$ coefficient being positive, an increase in the L/S ratio used for the extrudate production will tend to make the fiberboard slightly denser. As a result, the densest board of the entire study was panel number $8\left(1414 \mathrm{~kg} / \mathrm{m}^{3}\right)$, and it was produced from values below the center of the experimental domain for both water added at molding and lignin content, i.e. 5\% and 8.9\%, respectively. The corresponding L/S ratio used during extrusion was in that case 0.4 . On the opposite, the two least dense boards, i.e. panels number 6 and 10 (1239 kg/m² and 1242 $\mathrm{kg} / \mathrm{m}^{3}$, respectively, for density), were both logically produced from a high amount of lignin (23.3\% and $19.7 \%$, respectively).

As a preliminary comment, when looking at the correlation coefficients obtained for the different polynomial models, it appears that all these $\mathrm{R}^{2}$ coefficients were at least 0.82 , except those related to the bending properties for which the correlation coefficient varied from 0.52 to 0.58 . This means that the best-fit second-order responses for maximum flexural strength and elastic modulus were less close to the values obtained experimentally by comparison with the other 
fiberboard characteristics analyzed. However, looking at the polynomial models related to breaking load, maximum flexural strength and elastic modulus, the bending properties were improved as lignin content increased inside the material, as illustrated by the positive values of the associated $a_{2}$ coefficients (Table 7). This confirmed the binding ability of lignin inside boards, as observed when comparing flexural properties of boards 5 and 3, and then of boards 4 and 6 , where lignin content increased from 1.7 to $23.3 \%$ while maintaining the same amounts of water (15\% and 5\%, respectively) and the same L/S ratio (0.7) (Table 5). On the contrary, the two other molding parameters, i.e. water added at molding and L/S ratio during extrusion had negative effects on the mechanical properties of fiberboards, as the $\mathrm{a}_{1}$ and $\mathrm{a}_{3}$ coefficients were negative (Table 7). Nonetheless, it has to be noted that the $\mathrm{a}_{3}$ coefficient was non-significant for the maximum flexural strength response. In the same way, the $a_{2}$ coefficient was non-significant for the elastic modulus response. Thus, when more moisture is added at molding and when the L/S ratio used for the extrudate production is high, the boards obtained are more fragile in a bending point of view. The finding that moisture content has a negative impact on the mechanical properties is in agreement with Miki et al. (2003) and Mobarak et al. (1982). On the one hand, more water has probably improved the lignin mobilization at molding through plasticization (Yamashita et al. 2007, Yamashita et al. 2009). On the other hand, however, because the matrix was still wet when the hydraulic press opened, this could possibly result in degassing phenomena. In a practical point of view, degassing was indeed observed for the highest values of water added at molding, especially for boards number 1 and 5 for which $20 \%$ and $15 \%$ water was added at molding, respectively. This resulted in the appearance of cracks inside these two boards, these defects having been observed after the cutting of the test specimens. This is the most likely reason explaining that boards number 1 and 5 were particularly fragile from a mechanical point of view (Table 1). Concerning the effect of the L/S ratio during extrusion, a high value of this ratio (1.0) maintains a higher length for fibers (Table 4), even after crushing. And, despite a higher rate of fines in that case, it is reasonable to assume that the higher fiber length observed at 1.0 L/S ratio thus reduced their specific surface area, contributing to rather weak mechanical properties for the corresponding boards, i.e. boards number 7, 11 and 12 (Shen 1986).

The binding ability of lignin was previously evidenced when comparing boards molded from the same extruded fibers and with the same amount of water added at molding. This resulted in an improvement in the boards' bending properties. However, the interest for its addition could be no longer predominant when the amount of water added at molding was at the same time too high. Indeed, when comparing boards number 3 and 6 for which the lignin content was $23.3 \%$ in both cases, the addition of more water at molding (15\% for board number 3 instead of only $5 \%$ for board number 6) resulted in a $12 \%$ reduction for maximum flexural strength and elastic modulus. As previously reported, this was due to more water vapor escaping from the fibrous material at the press opening, which resulted in the generation of more defects inside board number 3 . Thus, the most mechanically resistant fiberboard in bending of the entire study was board 
number 8 , and it was produced from the next molding parameters: 5.0\% water added at molding (i.e. $\mathrm{X}_{1}=-0.500$ ), $8.9 \%$ lignin content (i.e. $\mathrm{X}_{2}=-0.289$ ), and $0.4 \mathrm{~L} / \mathrm{S}$ ratio used during extrusion (i.e. $\mathrm{X}_{3}=-0.816$ ). Although the lignin content was not the highest one of the study in that case, this fiberboard was produced using a very little amount of water added at molding, thus limiting the tendency to degassing, and from fibers which were refined with the minimal L/S ratio during extrusion, thus revealing a reduced mean length and higher specific surface area. In addition, this most mechanically resistant board was also the densest one (Table 5). In parallel, results revealed a clear correlation between fiberboard density and bending properties. Indeed, except for board number 6 whose lignin content was maximal (i.e. 23.3\%), the more the density of fiberboard, the more its maximum flexural strength (Fig. 3) and the more its elastic modulus (Fig. 4). And, this was in accordance with a previous study dealing with biodegradable fiberboards made from a deoiled sunflower cake using also hot pressing (Evon et al. 2015). Because all fiberboards had not exactly the same thicknesses (from 3.1 to $4.0 \mathrm{~mm}$ ) and thus the same densities, their specific maximum flexural strength and their specific elastic modulus, defined as the ratio of the bending characteristic to the board density, were also calculated (Table 5). The findings revealed that the maximal specific values for both maximum flexural strength and elastic modulus were obtained for board number 6 and not for board number 8 (Table 5). This fiberboard was produced from the next molding parameters: 5.0\% water added at molding (i.e. $\mathrm{X}_{1}=-0.500$ ), 23.3\% lignin content (i.e. $\mathrm{X}_{2}=0.866$ ), and $0.7 \mathrm{~L} / \mathrm{S}$ ratio used during extrusion (i.e. $\mathrm{X}_{3}=0.000$ ). These results for specific bending properties confirmed that lignin addition is required in order to enhance the mechanical properties of the fiberboard, as observed when comparing boards 5 and 3, or boards 4 and 6 . On the contrary, too large amounts of water added at molding did not improve the final boards' properties as degassing phenomena could occur in that case, thus causing the appearance of cracks inside the panels. However, a little water addition (5\%) was needed for a better lignin mobilization and plasticization (Orliac et al. 2003, Xu et al. 2006, Yamashita et al. 2009, Takahashi et al. 2010, Pintiaux et al. 2015). Lastly, these findings also evidenced that a low (0.4) or medium (0.7) L/S ratio during extrusion, which led to the shortening of fibers in length inside these two extrudates and thus to the lowering of their aspect ratios, from 15.0 for $1.0 \mathrm{~L} / \mathrm{S}$ ratio to 11.3 for $0.4 \mathrm{~L} / \mathrm{S}$ ratio (Table 4), provided a better resistance of boards at bending. Among the most likely reasons, this evolution might be explained as results of (i) a facilitated compaction at thermo-pressing of these shorter fibers, (ii) their increased specific surface area, and (iii) a facilitated access to the components inside the cell walls from rice straw (Shen 1986).

The isoresponse curves for maximum flexural strength and specific maximum flexural strength are shown in Fig. 5. The ones for elastic modulus and specific elastic modulus are represented in Fig. 6. These isoresponse curves illustrate the influence of the molding parameters on the boards' bending properties. At $0.7 \mathrm{~L} / \mathrm{S}$ ratio used for the extrudate production (i.e. $\mathrm{X}_{3}=0.0$ ), both maximum flexural strength and specific maximum flexural strength tended to increase as lignin content increased and water added at molding decreased (Fig. 5a and 5d). At 12.5\% lignin content (i.e. $\mathrm{X}_{2}=0.0$ ) 
and at high level of water added, both maximum flexural strength and specific maximum flexural strength tended to increase as the L/S ratio used during extrusion also increased (Fig. 5b and 5e). On the contrary, for low amounts of water, these isoresponse curves also revealed that bending strengths improved with the lowering of the L/S ratio used for the extrudate production. Nonetheless, when comparing these two opposite phenomena between them, the increase in the bending strengths was much more significant at low amount of water added simultaneously with low L/S ratio used at extrusion than at high water added at molding and high L/S ratio. Lastly, Fig. 5c and $5 f$ show the evolution of both maximum flexural strength and specific maximum flexural strength as functions of lignin content and L/S ratio used at extrusion for a $10 \%$ water added at molding (i.e. $\mathrm{X}_{1}=0.0$ ): more lignin added simultaneously with a progressive lowering in the L/S ratio tended to increase bending strengths of boards. For the elastic modules, their evolutions at $0.7 \mathrm{~L} / \mathrm{S}$ ratio used for the extrudate production (i.e. $\mathrm{X}_{3}=0.0$ ) are presented in Fig. $6 \mathrm{a}$ and $6 \mathrm{~d}$. These modules increased when decreasing the proportion of water added until an optimal value obtained at about 5\% water addition. In parallel, because of its binding ability, the more the lignin content with $5 \%$ water added, the more the specific elastic modulus (Fig. 6d). At $12.5 \%$ lignin content (i.e. $\mathrm{X}_{2}=0.0$ ), Fig. $6 \mathrm{~b}$ and $6 \mathrm{e}$ showed that the decrease in the water added at molding provided better rigidity for the panel, the optimal value for both elastic modules being obtained at about $5 \%$ water added at molding. In addition, from this optimized water amount, boards became more and more rigid as the $\mathrm{L} / \mathrm{S}$ ratio at extrusion decreased. Finally, for a $10 \%$ water added at molding (i.e. $\mathrm{X}_{1}=0.0$ ), the isoresponse curves (Fig. 6c \& 6f) showed an improvement in both elastic and specific elastic moduli when (i) more lignin was added simultaneously with the increase in the L/S ratio used for extrusion, or when (ii) lignin content and L/S ratio at extrusion were reduced at the same time.

Conversely, the Shore $D$ surface hardness and Charpy impact strength were relatively independent on the molding parameters (Table 7). Shore $D$ was quite high with a $79.3^{\circ}$ mean value in the whole Doehlert's experimental design, due to the high density obtained for all fiberboards manufactured. On the contrary, boards were not highly resistant to impact, i.e. only $3.2 \mathrm{~kJ} / \mathrm{m}^{2}$ for the mean impact resilience (Table 7), and such fragility could be explained by the high rigidity of the boards manufactured (Table 5 and 6). These results were in agreement with a previous study of Evon et al. (2015) dealing with boards originating from sunflower whole plant.

Thickness swelling (TS) and water absorption (WA) of fiberboards were both influenced by the molding parameters (Table 7). The negative values of $\mathrm{a}_{1}$ and especially $\mathrm{a}_{2}$ coefficients in the associated polynomial models illustrated clearly that the more water added at molding and especially the more the lignin content, the more the water resistance of the obtained fiberboards. The maximal TS and WA values were $35 \%$ and $32 \%$, respectively, corresponding to panel number 5 (Table 6). On the contrary, the lowest ones were only $10 \%$ and $7 \%$, respectively, corresponding to panel number 3 (15\% water added, 23.3\% lignin content, and $0.7 \mathrm{~L} / \mathrm{S}$ ratio at extrusion). The isoresponse curves for thickness swelling are presented in Fig. 7. In particular, at $0.7 \mathrm{~L} / \mathrm{S}$ ratio at extrusion (i.e. $\mathrm{X}_{3}=0.0$ ), thickness swelling 
decreased rapidly (i.e. from 35\% max up to less than 10\%) with the simultaneous increases in both water added at molding and lignin content (Fig. 7a). The findings in Fig. 7 revealed that the least sensitive boards to water (10-12\% TS values) were obtained from molding conditions using maximum lignin content (Fig 7a and 7c), simultaneously with the use of extrudates produced from L/S ratios less than 0.7 (Fig. 7c).

Polynomial models were used to determine the optimal responses for each fiberboard characteristic analyzed, i.e. density, bending properties, impact resilience, shore $D$ surface hardness, and thickness swelling. All optimal responses and the relevant molding conditions are given in Table 8. Depending on the characteristic studied, optimal molding variables were not always the same. The optimal $\mathrm{X}_{1}$ coding value was -1.0 , i.e. $0 \%$ water added, for density, breaking load, maximum flexural strength, specific maximum flexural strength, and shore $D$ surface hardness. The other optimal $\mathrm{X}_{1}$ coding values were about -0.55 (i.e. $4.5 \%$ water added) for modulus of elasticity and specific modulus of elasticity, and 1.0 (i.e. 20\% water added) for Charpy impact strength and thickness swelling. The optimal $\mathrm{X}_{2}$ coding value was mostly 1.0 (i.e. 25\% lignin content), especially for breaking load, specific maximum flexural strength, specific elastic modulus, Shore $D$ surface hardness, and thickness swelling (Table 8). Lastly, the optimal $\mathrm{X}_{3}$ coding value was -1.0 (i.e. $0.33 \mathrm{~L} / \mathrm{S}$ ratio at extrusion) for density and board's bending properties. On the contrary, it was 1.0 for surface hardness and Charpy impact strength, and -0.16 for thickness swelling.

Additionally, an analysis was performed to find the molding parameters to be used for having all the characteristics studied as near as possible to the optimal values identified for each of them (Table 8). The corresponding $\mathrm{X}_{1}, \mathrm{X}_{2}$, and $\mathrm{X}_{3}$ coding values thus identified were $-1.0,1.0$ and -1.0 , respectively, corresponding to the next molding parameters: $0 \%$ water added at molding, 25\% lignin addition, and $0.33 \mathrm{~L} / \mathrm{S}$ ratio used for the extrudate production (Table 9). From these parameters and using the polynomial models for each fiberboard characteristic analyzed, the optimized material thus thermo-pressed will have a $1102 \mathrm{~kg} / \mathrm{m}^{3}$ density instead of $1593 \mathrm{~kg} / \mathrm{m}^{3}$ for the maximal density value (i.e. $31 \%$ reduction). In parallel, the maximum flexural strength and the elastic modulus would be approximately 50 MPa and 6.0 GPa, respectively. Such flexural properties are lower than the maximal ones (i.e. 55 MPa and 9.2 GPa, respectively) but not so much, in particular for maximum flexural strength. In addition, they were perfectly comparable with results obtained from other studies dealing also with the manufacture of fiberboards using hot pressing (Anglès et al. 2001, Okuda et al. 2006, Halvarsson et al. 2008, Halvarsson et al. 2009, Mancera et al. 2012, Theng et al. 2015, Theng et al. 2017b).

The bending properties of the optimized board would largely comply with French standard NF EN 312 (standard dedicated to the specifications for particleboards), for P7 type boards, i.e. load bearing boards for use under high stress and in wet conditions (recommendations of $20 \mathrm{MPa}$ and $3 \mathrm{GPa}$ for maximum flexural strength and elastic modulus, 
respectively, for boards with a thickness of between 3 and $4 \mathrm{~mm}$ ). Nonetheless, the $10 \%$ required thickness swelling is not achieved for the moment. However, an additional process previously tested successfully by some other authors (Widyorini et al. 2005, Okuda et al. 2006, Halvarsson et al. 2009, Saadaoui et al. 2013, Evon et al. 2015, Uitterhaegen et al. 2017) such as preheating, chemical, or steam treatment would probably improve this dimensional stability parameter.

Lastly, the optimized board would also reveal a better mechanical resistance than that of a commercial fiberboard made from eucalyptus and pine wood sawdust as reinforcing fibers, and urea-formaldehyde resin as binder (42 MPa and 2.7 GPa for maximum flexural strength and elastic modulus, respectively, for this commercial board having quite the same thickness, i.e. about $3 \mathrm{~mm}$ ). However, it would be a little denser than this commercial material (i.e. $1102 \mathrm{~kg} / \mathrm{m}^{3}$ density instead of $883 \mathrm{~kg} / \mathrm{m}^{3}$ ) (Theng et al., 2015, 2017b).

In conclusion, the optimized experimental laboratory fiberboard made from rice straw thermo-mechanical extrudate plus Biolignin ${ }^{\mathrm{TM}}$ as natural binder appeared as a good compromise between bending properties and density, leading to a quite high mechanical resistance while maintaining a low density value. However, it has to be noted that such density is still a little higher compared with most commercial hardboards (around $1000 \mathrm{~kg} / \mathrm{m}^{3}$ ), which could result in some difficulties in handling them. This high panel density is the result of the absence of synthetic resin, the use of thermopressing with high temperature and pressure being necessary to mobilize the lignin-based binder during hot pressing (Tajuddin et al. 2016). The next step of this work could consist in optimizing the molding conditions, in particular by reducing the applied pressure and the molding time while maintaining as much as possible the board's mechanical properties at a high level. On the one hand, a pressure reduction should contribute to the lowering of the board density, which will undoubtedly favor its subsequent handling. On the other hand, a molding time reduction would be more economical. To remain competitive in terms of molding cost compared with commercial particleboards, in particular the ones produced in industry for indoor use, it should ideally not exceed 30 sec per mm thickness, corresponding to a maximal molding time of 120 sec for a 4 mm thickness fiberboard.

\section{Conclusion}

Novel biodegradable and cohesive fiberboards were manufactured using a heated hydraulic press from rice straw extrudates produced using a thermo-mechanical pretreatment in a twin-screw extruder, i.e. without chemical reaction. Lignin and water added at molding acted as a natural binder and a lignin plasticizer, respectively, and lignocellulosic fibers also acted as mechanical reinforcement. The molding parameters (i.e. water added at molding, lignin content, and L/S ratio used for the extrudate production in the twin-screw extruder) influenced the boards' mechanical and physical 
properties. From all fiberboards manufactured according to a Doehlert's experimental design, the best flexural properties corresponded to a board made from the extrudate produced using the lowest L/S ratio for twin-screw extrusion (i.e. 0.4). The latter was molded with 5\% water added and with $8.9 \%$ lignin content. Density of such material was high (i.e. 1414 $\mathrm{kg} / \mathrm{m}^{3}$ ), making it a hardboard; maximum flexural strength and elastic modulus were 50.3 MPa and 8.6 GPa, respectively. These values were the highest ones for the entire study. Thickness swelling and water absorption were $24 \%$ and $18 \%$, respectively. Such board largely complied with French standard NF EN 312, type P7 (i.e. load bearing boards for use under high stress and in wet conditions) in terms of bending properties, although a post-treatment should be required to improve its water resistance (10\% requirement for thickness swelling). Using the statistical analysis following Doehlert's experimental design, a good compromise between flexural properties and density could be obtained from the next molding parameters: $0 \%$ water added at molding, $25 \%$ lignin content, and $0.33 \mathrm{~L} / \mathrm{S}$ ratio used for the extrudate production. From such parameters, the fiberboard produced without chemical reagent or synthetic resin addition would reveal a density of $1102 \mathrm{~kg} / \mathrm{m}^{3}$, a maximum flexural strength of $50 \mathrm{MPa}$, and an elastic modulus of $6.0 \mathrm{GPa}$. These properties would comply with French standard NF EN 312, type P7.

\section{Acknowledgements}

The authors wish to thank the Erasmus+ KA107 project for financial support. Special sincere gratitude is given to Laboratoire de Chimie Agro-Industrielle (LCA), INP-ENSIACET, Toulouse, France for both raw materials and experimental support, and to CIMV company for having supplied Biolignin ${ }^{\mathrm{TM}}$.

\section{References}

Anglès MN, Ferrando F, Farriol X, Salvadó J (2001) Suitability of steam exploded residual softwood for the production of binderless panels. Effect of the pre-treatment severity and lignin addition. Biomass and Bioenerg 21: 211224.

Back EL (1987) The bonding mechanism in hardboard manufacture review report. Holzforsch-Int J Biol, Chem, Phys Technol Wood 41: 247-258.

CIMV TBC (2014) MSDS (CE) No 453/2010 Biolignin. CIMV, France.

Evon Ph, Barthod-Malat B, Grégoire M, Vaca-Medina G, Labonne L, Ballas S, Véronèse T, Ouagne P (2018)

Production of fiberboards from shives collected after continuous fiber mechanical extraction from oleaginous flax. J Nat Fibers. doi:10.1080/15440478.2017.1423264 
Evon P, Vandenbossche V, Pontalier P-Y, Rigal L (2010) The twin-screw extrusion technology, an original and powerful solution for the biorefinery of sunflower whole plant. 18th European Biomass Conference and Exhibition, Lyon, France, Open Archieve Toulouse Archieve Ouverte (OATAO).

Evon P, Vandenbossche V, Pontalier P-Y, Rigal L (2014) New thermal insulation fiberboards from cake generated during biorefinery of sunflower whole plant in a twin-screw extruder. Ind Crops Prod 52: 354-362.

Evon P, Vinet J, Labonne L, Rigal L (2015) Influence of thermo-pressing conditions on the mechanical properties of biodegradable fiberboards made from a deoiled sunflower cake. Ind Crops Prod 65: 117-126.

Gosselink RJ, van Dam JE, de Jong E, Gellerstedt G, Scott EL, Sanders JP (2011) Effect of periodate on lignin for wood adhesive application. Holzforsch 65: 155-162.

Halvarsson S, Edlund H, Norgren M (2008) Properties of medium-density fibreboard (MDF) based on wheat straw and melamine modified urea formaldehyde (UMF) resin. Ind Crops Prod 28: 37-46.

Halvarsson S, Edlund H, Norgren M (2009) Manufacture of high-performance rice-straw fiberboards. Ind Eng Chem Res 49: 1428-1435.

Kim S, Dale BE (2004) Global potential bioethanol production from wasted crops and crop residues. Biomass and Bioenerg 26: 361-375.

Konica Minolta Sensing (2007) Let's study color. In: Precise color communication. Konica Minolta, Inc. Tokyo, Part I.

Lin Z, Liu L, Li R, Shi J (2012) Screw extrusion pretreatments to enhance the hydrolysis of lignocellulosic biomass. J Microb Biochem Technol. doi: 10.4172/19485948.S12-002.

Mancera C, El Mansouri N-E, Pelach MA, Francesc F, Salvadó J (2012) Feasibility of incorporating treated lignins in fiberboards made from agricultural waste. Waste Manag 32: 1962-1967.

Mason W (1928) Process of making structural insulating boards of exploded lignocellulose fiber. MF Company.

Miki T, Takakura N, Iizuka T, Yamaguchi K, Kanayama K (2003) Possibility of extrusion of wood powders. JSME Int J Ser A Solid Mech Mater Eng 46: 371-377.

Mobarak F, Fahmy Y, Augustin H (1982) Binderless lignocellulose composite from bagasse and mechanism of selfbonding. Holzforsch Int J Biol Chem Phys Technol Wood 36: 131-136.

Murugan P, Mahinpey N, Johnson KE, Wilson M (2008) Kinetics of the pyrolysis of lignin using thermogravimetric and differential scanning calorimetry methods. Energ Fuels 22: 2720-2724.

NEMRODW (2015) A performing software for the design and analysis of experimental plans. http://www.nemrodw.com/idex.php. Accessed 1 September 2016.

Okuda N, Hori K, Sato M (2006) Chemical changes of kenaf core binderless boards during hot pressing (II): effects on the binderless board properties. J Wood Sci 52: 249-254. 
Orliac O, Rouilly A, Silvestre F, Rigal L (2003) Effects of various plasticizers on the mechanical properties, water resistance and aging of thermo-moulded films made from sunflower proteins. Ind Crops Prod 18: 91-100.

Ouagne P, Barthod-Malat B, Evon Ph, Labonne L, Placet V (2017) Fibre extraction from oleaginous flax for technical textile applications: influence of pre-processing parameters on fibre extraction yield, size distribution and mechanical properties. Procedia Eng 200: 213-220.

Pintiaux T, Viet D, Vandenbossche V, Rigal L, Rouilly A (2015) Binderless materials obtained by thermo-compressive processing of lignocellulosic fibers: a comprehensive review. BioResour 10: 1915-1963.

Saadaoui N, Rouilly A, Fares K, Rigal L (2013) Characterization of date palm lignocellulosic by-products and selfbonded composite materials obtained thereof. Mater Des 50: 302-308.

Shen KC (1986) Process for manufacturing composite products from lignocellulosic materials. US4627951A Patent. Tajuddin M, Ahmad Z, Ismail H (2016) A review of natural fibers and processing operations for the production of binderless boards. BioResour 11: 5600-5617.

Takahashi I, Sugimoto T, Takasu Y, Yamasaki M, Sasaki Y, Kikata Y (2010) Preparation of thermoplastic molding from steamed Japanese beech flour. Holzforsch-Int J Biol Chem Phys Technol Wood 64: 229-234.

Theng D (2017) Feasibility of incorporating treated lignin and cellulose nanofiber in fiberboards made from corn stalk and rice straw. Ph.D thesis, University of Girona, Spain.

Theng D, Arbat G, Delgado-Aguilar M, Vilaseca F, Ngo B, Mutjé P (2015) All-lignocellulosic fiberboard from corn biomass and cellulose nanofibers. Ind Crops Prod 76: 166-173.

Theng D, Arbat G, Delgado-Aguilar M, Ngo B, Labonne L, Evon P, Mutjé P (2017a). Comparison between two different pretreatment technologies of rice straw fibers prior to fiberboard manufacturing: Twin-screw extrusion and digestion plus defibration. Ind Crops Prod 107: 184-197.

Theng D, El Mansouri N, Arbat G, Ngo B, Delgado-Aguilar M, Àngels Pelach M, Fullana-i-Palmer P, Mutje P (2017b) Fiberboards made from corn stalk thermomechanical pulp and kraft lignin as green adhesive. BioResour 12: 2379-2393.

Uitterhaegen E, Labonne L, Merah O, Talou T, Ballas S, Véronèse T, Evon P (2017) Optimization of thermopressing conditions for the production of binderless boards from a coriander twin-screw extrusion cake. J Appl Polym Sci 134. doi: 10.1002/app.44650.

Uitterhaegen E, Nguyen QH, Merah O, Stevens CV, Talou T, Rigal L, Evon P (2016) New Renewable and Biodegradable Fiberboards from a Coriander Press Cake. J Renew Mater 4: 225-238. 
Van Dam JE, van den Oever MJ, Teunissen W, Keijsers ER, Peralta AG (2004) Process for production of high density/high performance binderless boards from whole coconut husk: Part 1: Lignin as intrinsic thermosetting binder resin. Ind Crops Prod 19: 207-216.

Van Soest PJ, Wine RH (1967) Use of detergents in the analysis of fibrious feeds. IV. Determination of plant cell wall constituents. J Assoc Off Anal Chem 50: 50-55.

Van Soest PJ, Wine RH (1968) Determination of lignin and cellulose in acid detergent fiber with permanganate. J Assoc Off Anal Chem 51: 780-784.

Vandenbossche V, Brault J, Hernandez-Melendez O, Evon P, Barzana E, Vilarem G, Rigal L (2016) Suitability assessment of a continuous process combining thermo-mechano-chemical and bio-catalytic action in a single pilot-scale twin-screw extruder for six different biomass sources. Bioresour Technol 211: 146-153.

Vandenbossche V, Brault J, Vilarem G, Rigal L (2015) Bio-catalytic action of twin-screw extruder enzymatic hydrolysis on the deconstruction of annual plant material: case of sweet corn co-products. Ind Crops Prod 67: 239-248.

Widyorini R, Xu J, Umemura K, Kawai S (2005) Manufacture and properties of binderless particleboard from bagasse I: effects of raw material type, storage methods, and manufacturing process. J Wood Sci 51: 648.

Xu J, Widyorini R, Yamauchi H, Kawai S (2006) Development of binderless fiberboard from kenaf core. J Wood Sci 52: 236 .

Yamashita O, Imanishi H, Kanayama K (2007) Transfer molding of bamboo. J Mater Process Technol 192: 259-264.

Yamashita O, Yokochi H, Miki T, Kanayama K (2009) The pliability of wood and its application to molding. J Mater Process Technol 209: 5239-5244.

Zhang D, Zhang A, Xue L (2015) A review of preparation of binderless fiberboards and its self-bonding mechanism. Wood Sci Technol 49: 661-679. 
Table 1 Chemical composition, molecular weight and granulometry of the CIMV Biolignin ${ }^{\mathrm{TM}}$ extracted from wheat straw

\begin{tabular}{|c|c|c|c|c|c|c|c|c|c|c|}
\hline & \multirow[t]{2}{*}{ Water (\%) } & \multicolumn{4}{|c|}{ Chemical composition (\% of dry matter) } & \multicolumn{3}{|c|}{ Molecular weight (mmol/g) } & \multicolumn{2}{|c|}{ Granulometry } \\
\hline & & $\begin{array}{l}\text { Klasson lignin } \\
\text { (AIL + ASL) }\end{array}$ & Hemicelluloses & Ashes & Proteins & Aromatic $-\mathrm{OH}$ & Aliphatic -OH & $-\mathrm{COOH}$ & $<232 \mu \mathrm{m}$ & $<900 \mu \mathrm{m}$ \\
\hline Biolignin $^{\mathrm{TM}}$ & $<4$ & 89 & $\leq 4$ & 1.1 & $\approx 7$ & $2.0 \pm 0.2$ & $2.1 \pm 0.1$ & $0.6 \pm 0.0$ & $90 \%$ & $10 \%$ \\
\hline
\end{tabular}


Table 2 Molding parameters for the manufacture of the fourteen fiberboards (Doehlert's experimental design)

\begin{tabular}{|c|c|c|c|c|c|c|}
\hline Board number & $\mathrm{X}_{1}$ & $\begin{array}{c}\text { Water added at } \\
\text { molding (\%) }\end{array}$ & $\mathrm{X}_{2}$ & Lignin content (\%) & $\mathrm{X}_{3}$ & $\begin{array}{c}\text { L/S ratio during } \\
\text { extrusion }\end{array}$ \\
\hline 1 & 1.000 & 20.0 & 0.000 & 12.5 & 0.000 & 0.7 \\
\hline 2 & -1.000 & 0.0 & 0.000 & 12.5 & 0.000 & 0.7 \\
\hline 3 & 0.500 & 15.0 & 0.866 & 23.3 & 0.000 & 0.7 \\
\hline 4 & -0.500 & 5.0 & -0.866 & 1.7 & 0.000 & 0.7 \\
\hline 5 & 0.500 & 15.0 & -0.866 & 1.7 & 0.000 & 0.7 \\
\hline 6 & -0.500 & 5.0 & 0.866 & 23.3 & 0.000 & 0.7 \\
\hline 7 & 0.500 & 15.0 & 0.289 & 16.1 & 0.816 & 1.0 \\
\hline 8 & -0.500 & 5.0 & -0.289 & 8.9 & -0.816 & 0.4 \\
\hline 9 & 0.500 & 15.0 & -0.289 & 8.9 & -0.816 & 0.4 \\
\hline 10 & 0.000 & 10.0 & 0.577 & 19.7 & -0.816 & 0.4 \\
\hline 11 & -0.500 & 5.0 & 0.289 & 16.1 & 0.816 & 1.0 \\
\hline 12 & 0.000 & 10.0 & -0.577 & 5.3 & 0.816 & 1.0 \\
\hline 13 & 0.000 & 10.0 & 0.000 & 12.5 & 0.000 & 0.7 \\
\hline 14 & 0.000 & 10.0 & 0.000 & 12.5 & 0.000 & 0.7 \\
\hline
\end{tabular}


Table 3 Chemical composition of rice straw biomass and rice straw extrudates obtained after thermo-mechanical fractionation in the Clextral Evolum HT 53 twin-screw extruder (\% of dry matter)

\begin{tabular}{cccccc}
\hline Material & Minerals & Cellulose & Hemicelluloses & Lignin & Water-soluble \\
& & & & components \\
\hline Rice straw & $14.7 \pm 0.1^{\mathrm{a}}$ & $37.7 \pm 0.3^{\mathrm{a}}$ & $27.9^{\mathrm{a}} \pm 0.4^{\mathrm{a}}$ & $7.2 \pm 0.1^{\mathrm{a}}$ & $16.0^{\mathrm{a}} 0.1^{\mathrm{a}}$ \\
$\mathrm{E}_{1}(1.0 \mathrm{~L} / \mathrm{S}$ ratio $)$ & $14.3 \pm 0.2^{\mathrm{a}}$ & $36.2 \pm 0.5^{\mathrm{a}}$ & $33.0 \pm 0.6^{\mathrm{b}}$ & $5.5 \pm 0.5^{\mathrm{b}}$ & $15.9 \pm 0.1^{\mathrm{a}}$ \\
$\mathrm{E}_{2}(0.7 \mathrm{~L} / \mathrm{S}$ ratio $)$ & $14.4 \pm 0.1^{\mathrm{a}}$ & $37.0 \pm 0.9^{\mathrm{a}}$ & $28.4 \pm 0.2^{\mathrm{a}}$ & $6.8 \pm 0.3^{\mathrm{a}}$ & $17.3^{\mathrm{a}} \pm 0.3^{\mathrm{b}}$ \\
$\mathrm{E}_{3}(0.4 \mathrm{~L} / \mathrm{S}$ ratio $)$ & $15.8 \pm 0.0^{\mathrm{b}}$ & $33.8 \pm 0.1^{\mathrm{b}}$ & $29.3 \pm 0.2^{\mathrm{a}}$ & $6.3 \pm 0.2^{\mathrm{a}, \mathrm{b}}$ & $16.2^{\mathrm{b}} \pm 0.2^{\mathrm{a}}$
\end{tabular}

Means in the same column with the same superscript letter $(a-b)$ are not significantly different at $P<0.05$. 
Table 4 Morphological properties of extrudates before and after crushing using an Electra VS 1 hammer mill fitted with a $15 \mathrm{~mm}$ screen

\begin{tabular}{cccccc}
\hline & Material & $\mathrm{L}_{\mathrm{W}}(\mu \mathrm{m})$ & $\mathrm{D}(\mu \mathrm{m})$ & $\mathrm{L}_{\mathrm{W}} / \mathrm{D}$ (aspect ratio) & Fines (\%) \\
\hline Before & $\mathrm{E}_{1}(1.0 \mathrm{~L} / \mathrm{S}$ ratio $)$ & $571.5 \pm 7.8^{\mathrm{a}}$ & $25.5 \pm 0.0^{\mathrm{a}}$ & $22.4^{\mathrm{a}} \pm 0.3^{\mathrm{a}}$ & $63.8 \pm 0.4^{\mathrm{b}}$ \\
crushing & $\mathrm{E}_{2}(0.7 \mathrm{~L} / \mathrm{S}$ ratio $)$ & $571.0 \pm 7.1^{\mathrm{a}}$ & $25.3 \pm 0.0^{\mathrm{a}}$ & $22.6 \pm 0.3^{\mathrm{a}}$ & $54.2 \pm 4.9^{\mathrm{a}}$ \\
& $\mathrm{E}_{3}(0.4 \mathrm{~L} / \mathrm{S}$ ratio $)$ & $494.0 \pm 1.4^{\mathrm{b}}$ & $23.7 \pm 0.1^{\mathrm{b}}$ & $20.9 \pm 0.1^{\mathrm{b}}$ & $61.9 \pm 0.5^{\mathrm{b}}$ \\
\hline After & $\mathrm{E}_{1}(1.0 \mathrm{~L} / \mathrm{S}$ ratio $)$ & $346.0 \pm 7.1^{\mathrm{a}}$ & $23.1 \pm 0.1^{\mathrm{a}}$ & $15.0 \pm 0.4^{\mathrm{a}}$ & $86.6 \pm 0.7^{\mathrm{a}}$ \\
crushing & $\mathrm{E}_{2}(0.7 \mathrm{~L} / \mathrm{S}$ ratio $)$ & $306.0 \pm 8.5^{\mathrm{b}}$ & $23.4 \pm 0.6^{\mathrm{a}}$ & $13.1 \pm 0.0^{\mathrm{b}}$ & $75.1 \pm 1.3^{\mathrm{b}}$ \\
& $\mathrm{E}_{3}(0.4 \mathrm{~L} / \mathrm{S}$ ratio $)$ & $270.0 \pm 2.8^{\mathrm{c}}$ & $23.8 \pm 0.4^{\mathrm{a}}$ & $11.3 \pm 0.3^{\mathrm{c}}$ & $66.7^{\mathrm{a}} \pm 3.5^{\mathrm{c}}$ \\
\hline
\end{tabular}

Means in the same column with the same superscript letter (a-b before crushing and a-c after crushing) are not significantly different at $P<0.05$. 
Table 5 Mechanical properties of the fourteen fiberboards manufactured by thermo-pressing

\begin{tabular}{|c|c|c|c|c|c|c|c|c|c|c|}
\hline \multirow{2}{*}{$\begin{array}{l}\text { Board } \\
\text { number }\end{array}$} & \multirow[b]{2}{*}{$\mathrm{t}(\mathrm{mm})$} & \multicolumn{6}{|c|}{ Bending properties } & \multirow{2}{*}{$\begin{array}{c}\text { Surface hardness } \\
\text { Shore } D\left(^{\circ}\right)\end{array}$} & \multicolumn{2}{|c|}{ Charpy impact strength } \\
\hline & & $\mathrm{d}\left(\mathrm{kg} / \mathrm{m}^{3}\right)$ & $F(N)$ & $\sigma_{\mathrm{f}}(\mathrm{MPa})$ & $\mathrm{E}_{\mathrm{f}}(\mathrm{GPa})$ & $\begin{array}{c}\sigma_{\mathrm{f}} / \mathrm{d} \\
\left(\mathrm{kPa} \cdot \mathrm{m}^{3} / \mathrm{kg}\right)\end{array}$ & $\begin{array}{c}\mathrm{E}_{\mathrm{f}} / \mathrm{d} \\
\left(\mathrm{MPa} \cdot \mathrm{m}^{3} / \mathrm{kg}\right)\end{array}$ & & $\mathrm{W}(\mathrm{mJ})$ & $\mathrm{K}\left(\mathrm{kJ} / \mathrm{m}^{2}\right)$ \\
\hline 1 & $3.6 \pm 0.5$ & $1273 \pm 126$ & $82.3 \pm 9.1$ & $27.9 \pm 4.4$ & $4.2 \pm 0.9$ & $21.8 \pm 2.1$ & $3.3 \pm 0.5$ & $78.6 \pm 0.0$ & $112.5 \pm 24.9$ & $2.4 \pm 0.6$ \\
\hline 2 & $3.6 \pm 0.2$ & $1337 \pm 48$ & $117.7 \pm 8.0$ & $38.3 \pm 3.6$ & $5.9 \pm 0.7$ & $28.6 \pm 2.2$ & $4.4 \pm 0.6$ & $79.6 \pm 0.3$ & $158.8 \pm 21.0$ & $3.3 \pm 0.4$ \\
\hline 3 & $3.6 \pm 0.1$ & $1360 \pm 46$ & $134.8 \pm 9.9$ & $41.6 \pm 2.9$ & $6.8 \pm 0.5$ & $30.7 \pm 2.2$ & $5.0 \pm 0.3$ & $79.7 \pm 0.3$ & $96.3 \pm 18.5$ & $1.7 \pm 0.6$ \\
\hline 4 & $3.1 \pm 0.1$ & $1390 \pm 136$ & $74.7 \pm 11.1$ & $33.1 \pm 5.5$ & $6.2 \pm 0.7$ & $23.1 \pm 5.2$ & $4.3 \pm 0.8$ & $79.2 \pm 0.0$ & $151.4 \pm 21.2$ & $3.4 \pm 0.6$ \\
\hline 5 & $3.2 \pm 0.1$ & $1300 \pm 91$ & $52.8 \pm 7.0$ & $22.9 \pm 1.7$ & $5.4 \pm 0.5$ & $18.2 \pm 2.0$ & $4.3 \pm 0.5$ & $78.8 \pm 0.3$ & $174.3 \pm 25.1$ & $4.3 \pm 0.8$ \\
\hline 6 & $3.7 \pm 0.1$ & $1239 \pm 145$ & $146.2 \pm 4.4$ & $47.1 \pm 6.0$ & $7.7 \pm 0.9$ & $38.8 \pm 9.2$ & $6.3 \pm 1.2$ & $79.9 \pm 0.3$ & $135.7 \pm 12.7$ & $2.9 \pm 0.7$ \\
\hline 7 & $3.7 \pm 0.2$ & $1324 \pm 103$ & $102.5 \pm 4.1$ & $31.1 \pm 1.3$ & $4.7 \pm 0.7$ & $23.8 \pm 1.3$ & $3.6 \pm 0.2$ & $78.7 \pm 0.2$ & $155.7 \pm 16.2$ & $3.4 \pm 0.4$ \\
\hline 8 & $3.2 \pm 0.1$ & $1414 \pm 98$ & $126.6 \pm 22.4$ & $50.3 \pm 9.0$ & $8.6 \pm 1.5$ & $35.7 \pm 8.7$ & $6.2 \pm 1.5$ & $79.7 \pm 0.1$ & $128.8 \pm 23.0$ & $3.0 \pm 0.5$ \\
\hline 9 & $3.4 \pm 0.2$ & $1326 \pm 34$ & $90.4 \pm 1.5$ & $31.8 \pm 0.5$ & $6.3 \pm 0.4$ & $24.0 \pm 0.7$ & $4.8 \pm 0.4$ & $79.3 \pm 0.1$ & $142.5 \pm 14.9$ & $3.2 \pm 0.4$ \\
\hline 10 & $4.0 \pm 0.3$ & $1242 \pm 84$ & $114.2 \pm 12.0$ & $30.0 \pm 2.6$ & $4.8 \pm 0.1$ & $23.5 \pm 2.6$ & $3.8 \pm 0.1$ & $79.2 \pm 0.5$ & $146.7 \pm 15.1$ & $2.3 \pm 0.6$ \\
\hline 11 & $3.7 \pm 0.1$ & $1330 \pm 19$ & $95.8 \pm 8.1$ & $31.6 \pm 5.0$ & $6.2 \pm 0.8$ & $23.8 \pm 3.5$ & $4.7 \pm 0.6$ & $79.9 \pm 0.4$ & $162.5 \pm 23.1$ & $3.3 \pm 0.5$ \\
\hline 12 & $3.3 \pm 0.1$ & $1350 \pm 18$ & $97.0 \pm 9.3$ & $37.6 \pm 3.3$ & $7.0 \pm 0.9$ & $27.8 \pm 2.2$ & $5.2 \pm 0.6$ & $79.3 \pm 0.4$ & $178.6 \pm 19.5$ & $4.3 \pm 0.7$ \\
\hline 13 & $3.5 \pm 0.2$ & $1318 \pm 47$ & $111.1 \pm 11.4$ & $34.9 \pm 5.8$ & $6.5 \pm 0.7$ & $26.5 \pm 4.6$ & $4.9 \pm 0.7$ & $79.3 \pm 0.1$ & $144.3 \pm 16.2$ & $3.1 \pm 0.3$ \\
\hline 14 & $3.5 \pm 0.1$ & $1332 \pm 17$ & $109.6 \pm 8.7$ & $38.0 \pm 3.1$ & $6.5 \pm 0.7$ & $28.5 \pm 2.5$ & $4.9 \pm 0.6$ & $79.4 \pm 0.3$ & $150.0 \pm 20.7$ & $3.2 \pm 0.5$ \\
\hline
\end{tabular}

t, thickness; d, density; F, breaking load for bending; $\sigma_{f}$, maximum flexural strength ; $E_{f}$, elastic modulus; $\sigma_{f} / d$, specific maximum flexural strength ; $E_{f} / d$, specific elastic modulus;

W, absorbed energy during Charpy impact test; $K$, impact resilience. 
Table 6 Physical properties of the fourteen fiberboards manufactured by thermo-pressing

\begin{tabular}{|c|c|c|c|c|c|c|}
\hline \multirow[t]{2}{*}{ Board number } & \multirow[t]{2}{*}{ TS (\%) } & \multirow[t]{2}{*}{ WA (\%) } & \multicolumn{4}{|c|}{ Color measurements } \\
\hline & & & $\mathrm{L}^{*}$ & $a^{*}$ & $\mathrm{~b}^{*}$ & $\Delta \mathrm{E}^{*}$ \\
\hline 1 & $17.3 \pm 3.5$ & $11.3 \pm 1.2$ & $67.5 \pm 0.6$ & $1.5 \pm 0.5$ & $2.5 \pm 0.7$ & 20.7 \\
\hline 2 & $22.3 \pm 1.7$ & $15.8 \pm 4.4$ & $68.7 \pm 1.5$ & $1.5 \pm 0.6$ & $3.5 \pm 1.6$ & 19.1 \\
\hline 3 & $10.1 \pm 2.5$ & $6.6 \pm 1.0$ & $67.8 \pm 0.7$ & $1.2 \pm 0.3$ & $2.5 \pm 0.7$ & 20.5 \\
\hline 4 & $22.4 \pm 2.2$ & $17.8 \pm 1.3$ & $69.7 \pm 1.2$ & $2.6 \pm 0.5$ & $5.1 \pm 1.3$ & 17.3 \\
\hline 5 & $35.2 \pm 7.6$ & $31.8 \pm 9.0$ & $71.1 \pm 1.8$ & $3.0 \pm 0.5$ & $6.5 \pm 1.7$ & 15.2 \\
\hline 6 & $16.2 \pm 3.2$ & $14.3 \pm 3.6$ & $68.4 \pm 1.3$ & $1.3 \pm 0.5$ & $3.1 \pm 1.2$ & 19.7 \\
\hline 7 & $15.6 \pm 4.2$ & $11.5 \pm 1.9$ & $68.4 \pm 0.9$ & $1.5 \pm 0.7$ & $3.1 \pm 1.3$ & 19.6 \\
\hline 8 & $23.6 \pm 2.7$ & $17.6 \pm 2.7$ & $68.0 \pm 0.7$ & $1.4 \pm 0.6$ & $2.8 \pm 0.9$ & 20.1 \\
\hline 9 & $28.4 \pm 2.8$ & $17.5 \pm 3.9$ & $67.8 \pm 0.6$ & $1.3 \pm 0.5$ & $2.6 \pm 0.8$ & 20.5 \\
\hline 10 & $14.3 \pm 1.4$ & $9.5 \pm 0.7$ & $67.2 \pm 0.4$ & $0.9 \pm 0.2$ & $1.8 \pm 0.5$ & 21.4 \\
\hline 11 & $21.8 \pm 0.9$ & $17.4 \pm 5.1$ & $69.0 \pm 1.0$ & $1.7 \pm 0.6$ & $4.0 \pm 1.3$ & 18.6 \\
\hline 12 & $23.3 \pm 1.4$ & $16.7 \pm 4.1$ & $69.1 \pm 1.7$ & $1.9 \pm 0.8$ & $4.1 \pm 1.9$ & 18.3 \\
\hline 13 & $16.5 \pm 1.9$ & $10.9 \pm 0.6$ & $68.4 \pm 1.1$ & $1.6 \pm 0.6$ & $3.3 \pm 1.3$ & 19.5 \\
\hline 14 & $16.9 \pm 1.9$ & $12.1 \pm 1.3$ & $68.1 \pm 1.0$ & $1.5 \pm 0.7$ & $3.1 \pm 1.3$ & 19.9 \\
\hline
\end{tabular}


Table 7 Coefficients of the best-fit second-order response for each of the fiberboard characteristics analyzed, and corresponding correlation coefficient $\left(\mathrm{R}^{2}\right)$

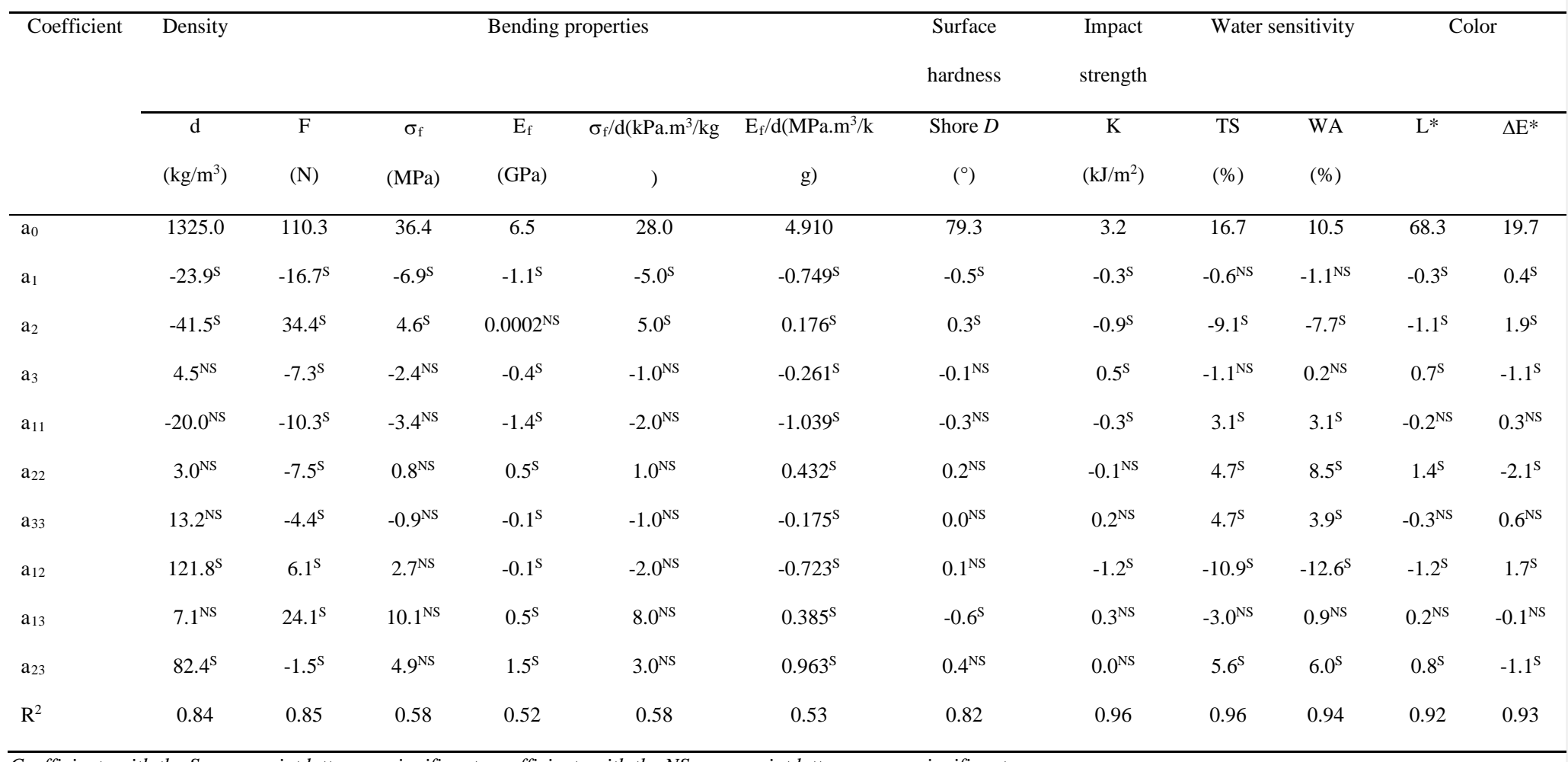

Coefficients with the S superscript letter are significant; coefficients with the NS superscript letter are non-significant. 
Table 8 Optimal molding condition identified for each of the fiberboard characteristics analyzed, and corresponding optimal response ( $\left.\mathrm{Y}_{\text {optimal }}\right)$

\begin{tabular}{|c|c|c|c|c|c|c|c|}
\hline Characteristic & $\overline{X_{1}}$ & $\begin{array}{l}\text { Water added at } \\
\text { molding (\%) }\end{array}$ & $\mathrm{X}_{2}$ & $\begin{array}{c}\text { Lignin content } \\
(\%)\end{array}$ & $\mathrm{X}_{3}$ & $\begin{array}{c}\text { L/S ratio } \\
\text { during } \\
\text { extrusion }\end{array}$ & $\mathrm{Y}_{\text {optimal }^{\mathrm{a}}}$ \\
\hline \multicolumn{8}{|c|}{ Bending properties } \\
\hline $\mathrm{d}\left(\mathrm{kg} / \mathrm{m}^{3}\right)$ & -1.00 & 0.0 & -1.00 & 0.0 & -1.00 & 0.33 & 1593.4 \\
\hline $\mathrm{F}(\mathrm{N})$ & -1.00 & 0.0 & 1.00 & 25.0 & -1.00 & 0.33 & 166.0 \\
\hline$\sigma_{\mathrm{f}}(\mathrm{MPa})$ & -1.00 & 0.0 & -1.00 & 0.0 & -1.00 & 0.33 & 55.2 \\
\hline $\mathrm{E}_{\mathrm{f}}(\mathrm{GPa})$ & -0.55 & 4.5 & -1.00 & 0.0 & -1.00 & 0.33 & 9.2 \\
\hline$\sigma_{\mathrm{f}} / \mathrm{d}$ & -1.00 & 0.0 & 1.00 & 25.0 & -1.00 & 0.33 & 44.0 \\
\hline \multicolumn{8}{|l|}{$\left(\mathrm{kPa} . \mathrm{m}^{3} / \mathrm{kg}\right)$} \\
\hline \multicolumn{8}{|l|}{$\left(\mathrm{MPa} \cdot \mathrm{m}^{3} / \mathrm{kg}\right)$} \\
\hline \multicolumn{8}{|l|}{ Surface hardness } \\
\hline Shore $D\left({ }^{\circ}\right)$ & -1.00 & 0.0 & 1.00 & 25.0 & 1.00 & 1.07 & 80.9 \\
\hline \multicolumn{8}{|c|}{ Charpy impact strength } \\
\hline $\mathrm{K}\left(\mathrm{kJ} / \mathrm{m}^{2}\right)$ & 1.00 & 20.0 & -1.00 & 0.0 & 1.00 & 1.07 & 5.8 \\
\hline \multicolumn{8}{|l|}{ Water sensitivity } \\
\hline TS (\%) & 1.00 & 20.0 & 1.00 & 25.0 & -0.16 & 0.64 & 3.7 \\
\hline
\end{tabular}

a The optimal response is the maximal one for fiberboard mechanical properties (i.e. flexural properties, Charpy impact strength, and Shore $D$ surface hardness), and the minimal one for thickness swelling. 
Table 9 Predicting value calculated from the corresponding polynomial model of each of the fiberboard mechanical properties analyzed for the molding conditions considered as a good compromise between density and flexural properties, i.e. $0 \%$ water added at molding $\left(\mathrm{X}_{1}=-1.00\right), 25 \%$ lignin content $\left(\mathrm{X}_{2}=1.00\right)$, and 0.33 liquid/solid ratio used for the extrudate production $\left(\mathrm{X}_{3}=-1.00\right)$

\begin{tabular}{ccc}
\hline Characteristic & Predicting value & Variation to the optimal value (\%) \\
\hline $\mathrm{d}\left(\mathrm{kg} / \mathrm{m}^{3}\right)$ & 1102.0 & 69.2 \\
$\mathrm{~F}(\mathrm{~N})$ & 166.0 & 100.0 \\
$\sigma_{\mathrm{f}}(\mathrm{MPa})$ & 49.6 & 89.7 \\
$\mathrm{E}_{\mathrm{f}}(\mathrm{GPa})$ & 6.0 & 65.7 \\
$\sigma_{\mathrm{f}} / \mathrm{d}\left(\mathrm{kPa} \cdot \mathrm{m}^{3} / \mathrm{kg}\right)$ & 44.0 & 100.0 \\
$\mathrm{E}_{\mathrm{f}} / \mathrm{d}\left(\mathrm{MPa} \cdot \mathrm{m}^{3} / \mathrm{kg}\right)$ & 5.2 & 79.6 \\
${\mathrm{Shore} D\left({ }^{\circ}\right)}_{\mathrm{K}\left(\mathrm{kJ} / \mathrm{m}^{2}\right)}$ & 79.1 & 97.9 \\
\hline
\end{tabular}




\section{Figure captions}

Fig. 1 Apparent and tapped densities of extrudates (a) before and (b) after crushing

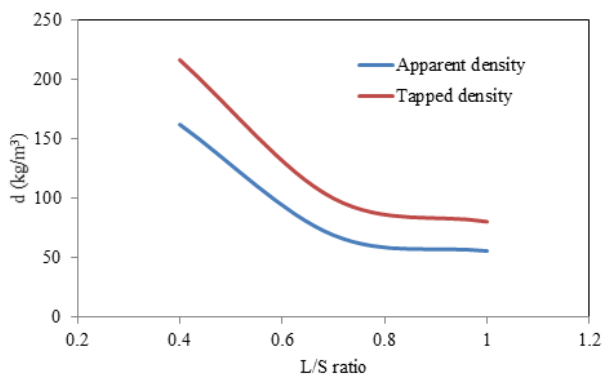

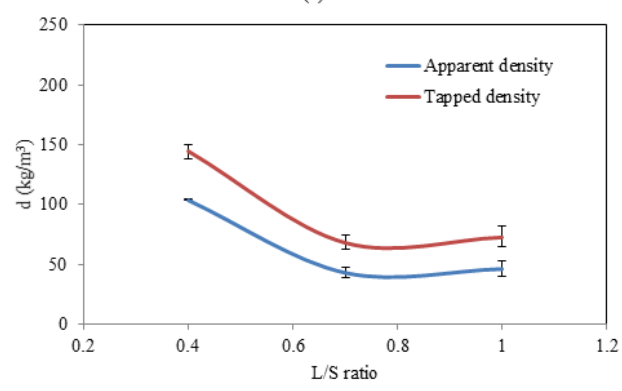

Fig. 2 TGA and dTGA curves of Biolignin ${ }^{\mathrm{TM}}$ extracted from wheat straw (from CIMV company)

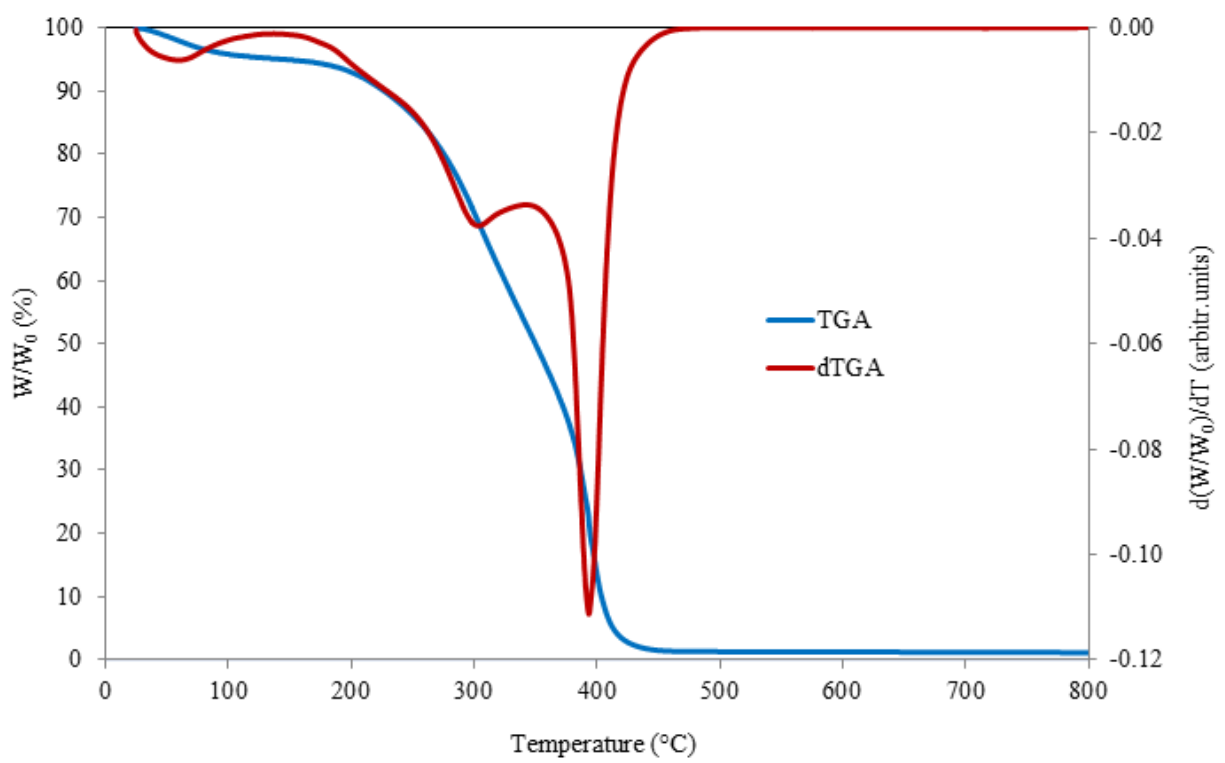

Fig. 3 Maximum flexural strength of fiberboards as a function of their density 


\section{Flexural strength vs. Density}

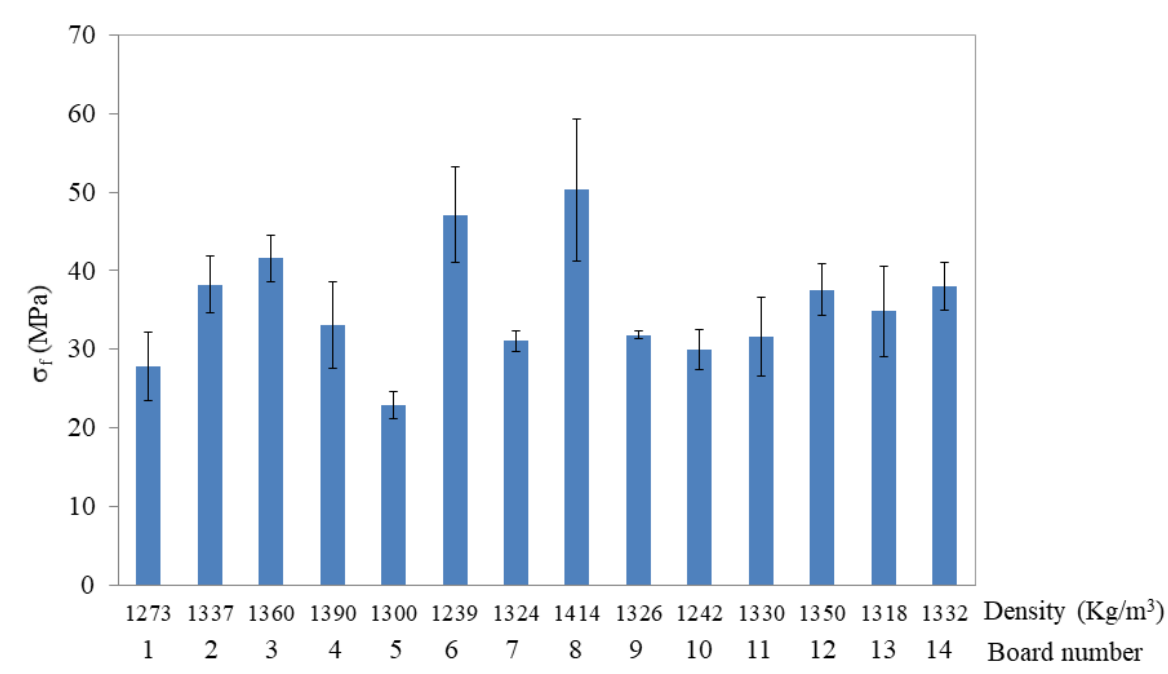

Fig. 4 Elastic modulus of fiberboards as a function of their density 


\section{Elastic modulus vs. Density}

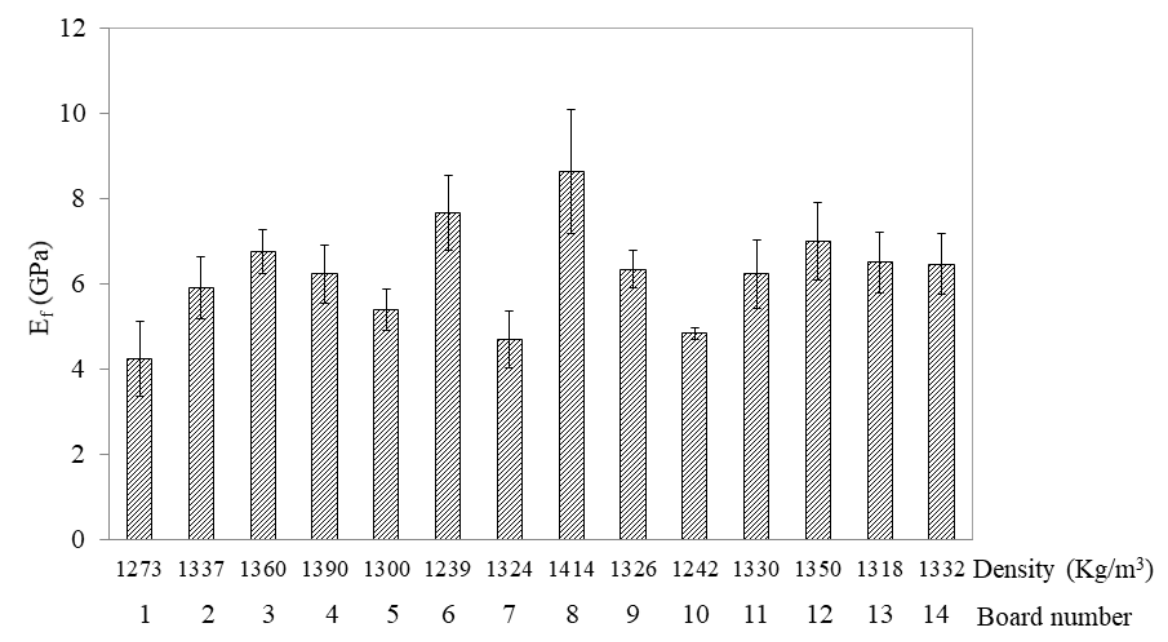

Fig. 5 Isoresponse curves of maximum flexural strength $\left(\sigma_{f}\right)$ of fiberboards (a) at $0.7 \mathrm{~L} / \mathrm{S}$ ratio for the extrudate production, (b) at $12.5 \%$ lignin content, and (c) at 10\% water added at molding, and of specific maximum flexural strength $\left(\sigma_{\mathrm{f}} / \mathrm{d}\right)(\mathrm{d})$ at $0.7 \mathrm{~L} / \mathrm{S}$ ratio for the extrudate production, (e) at $12.5 \%$ lignin content, and (f) at $10 \%$ water added at molding 
Maximum flexural strength $\left(\sigma_{\mathrm{f}}\right)$ of fiberboards
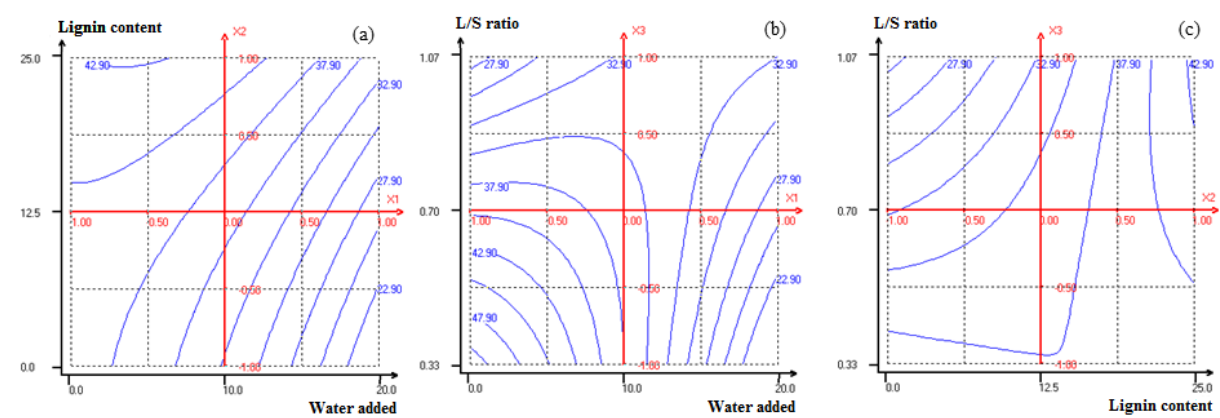

Specific maximum flexural strength $\left(\sigma_{\mathrm{f}} / \mathrm{d}\right)$ of fiberboards
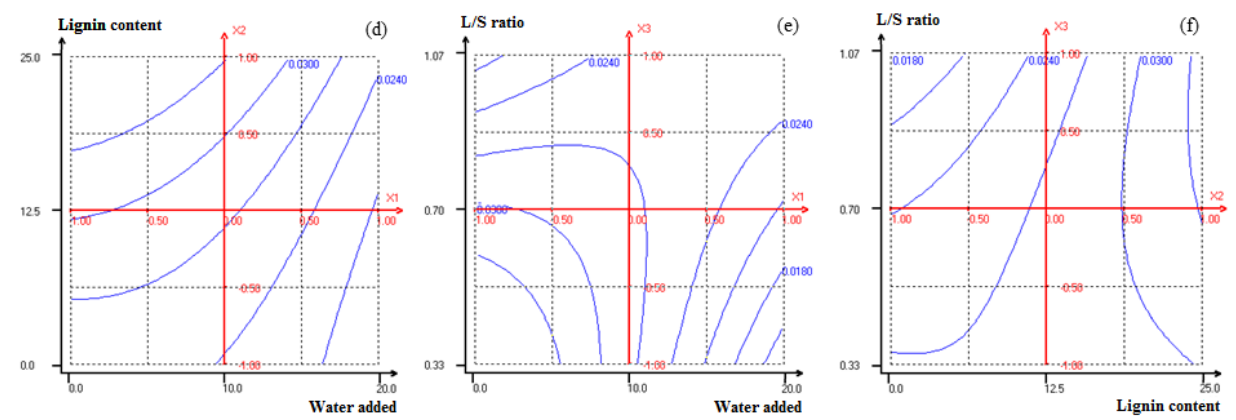

Fig. 6 Isoresponse curves of elastic modulus $\left(E_{f}\right)$ of fiberboards (a) at $0.7 \mathrm{~L} / \mathrm{S}$ ratio for the extrudate production, (b) at $12.5 \%$ lignin content, and (c) at 10\% water added at molding, and of specific elastic modulus ( $\left.\mathrm{E}_{\mathrm{f}} / \mathrm{d}\right)(\mathrm{d})$ at $0.7 \mathrm{~L} / \mathrm{S}$ ratio for the extrudate production, (e) at $12.5 \%$ lignin content, and (f) at $10 \%$ water added at molding 
Elastic modulus $\left(\mathrm{E}_{\mathrm{f}}\right)$ of fiberboards

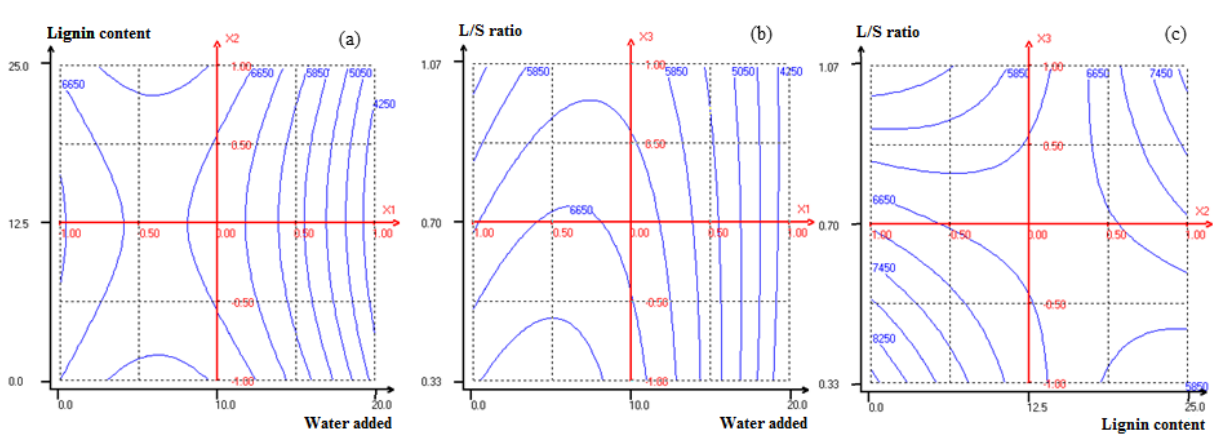

Specific elastic modulus $\left(E_{\mathrm{f}} / \mathbf{d}\right)$ of fiberboards

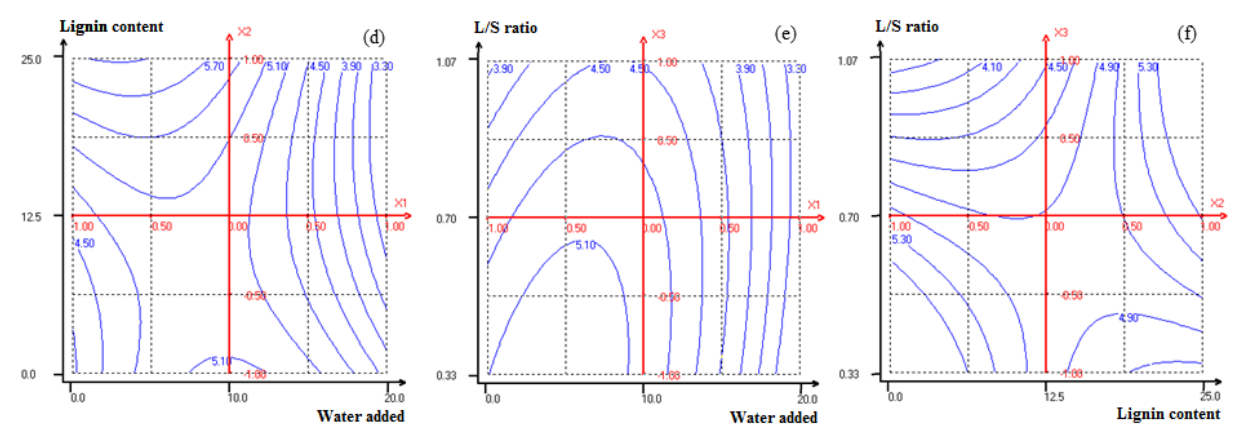

Fig. 7 Isoresponse curves of thickness swelling (TS) of fiberboards (a) at $0.7 \mathrm{~L} / \mathrm{S}$ ratio for the extrudate production, (b) at $12.5 \%$ lignin content, and (c) at $10 \%$ water added at molding 
Thickness swelling (TS) of fiberboards

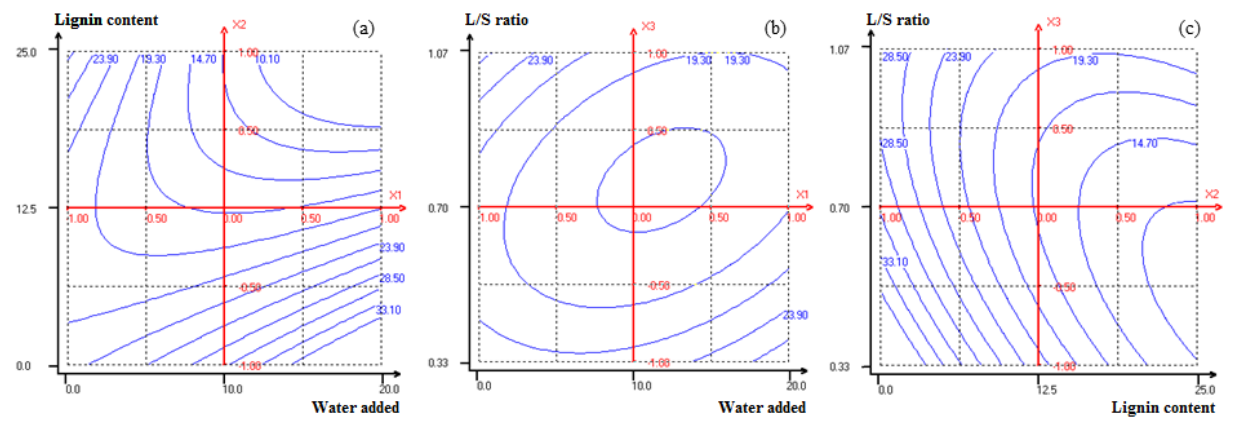

